IZA DP No. 8812

Pension Reform and Labor Supply:

Flexibility vs. Prescription

Erik Hernæs

Simen Markussen

John Piggott

Knut Røed

January 2015 


\title{
Pension Reform and Labor Supply: Flexibility vs. Prescription
}

\author{
Erik Hernæs \\ Ragnar Frisch Centre for Economic Research \\ Simen Markussen \\ Ragnar Frisch Centre for Economic Research \\ John Piggott \\ CEPAR and AIPAR, University of New South Wales \\ and IZA \\ Knut Røed \\ Ragnar Frisch Centre for Economic Research \\ and IZA
}

Discussion Paper No. 8812
January 2015

IZA

P.O. Box 7240

53072 Bonn

Germany

Phone: +49-228-3894-0

Fax: +49-228-3894-180

E-mail: iza@iza.org

Any opinions expressed here are those of the author(s) and not those of IZA. Research published in this series may include views on policy, but the institute itself takes no institutional policy positions. The IZA research network is committed to the IZA Guiding Principles of Research Integrity.

The Institute for the Study of Labor (IZA) in Bonn is a local and virtual international research center and a place of communication between science, politics and business. IZA is an independent nonprofit organization supported by Deutsche Post Foundation. The center is associated with the University of Bonn and offers a stimulating research environment through its international network, workshops and conferences, data service, project support, research visits and doctoral program. IZA engages in (i) original and internationally competitive research in all fields of labor economics, (ii) development of policy concepts, and (iii) dissemination of research results and concepts to the interested public.

IZA Discussion Papers often represent preliminary work and are circulated to encourage discussion. Citation of such a paper should account for its provisional character. A revised version may be available directly from the author. 


\section{ABSTRACT}

\section{Pension Reform and Labor Supply: Flexibility vs. Prescription*}

We exploit a comprehensive restructuring of the early retirement system in Norway in 2011 to examine labor supply responses to alternative pension reform strategies relying on improved work incentives (flexibility) or increased access ages (prescription), respectively. We find that increasing the returns to work is a powerful policy tool: The removal of the earnings test at age 63 led to an immediate increase in average annual labor earnings among the affected mature workers by around $\$ 14,700$ (NOK 90,000). The implied uncompensated labor earnings elasticity (the percentage change in average gross earnings relative to the percentage change in average work-incentives) is around 0.25 .

\section{NON-TECHNICAL SUMMARY}

Demographic imperatives are triggering pension reforms, especially social security reform, in many countries. These reforms typically have the twin aims of increasing mature labor force participation, and reducing the fiscal cost of social security. Reform initiatives often rely on prescription to achieve these aims, usually by increasing the age at which social security becomes available. But this is a fairly blunt approach: the heterogeneity of personal circumstances among mature aged workers leads to difficulties for many individuals, and often leads to increases in disability benefit payouts. An alternative approach, not tried very often, is to provide undistorted flexibility to mature workers: set up actuarially fair benefits, so that working longer is appropriately rewarded with higher pensions, and then allow flexibility in drawdown and labor force participation above some minimum age, so that workers may adjust their pension drawdown profile and work patterns without any impediment. While the 2011 Norwegian reform embraced the flexibility approach, the complexity of the pension system and the reform imply that groups are affected in different ways, thus allowing comparison of flexibility and prescription. We find that so far, the flexibility approach has been successful in delivering strong labor force participation outcomes. Prescription appears not to add much in terms of labor force participation, while giving increased disability inflow.

JEL Classification: H55, J22, J26

Keywords: early retirement, labor supply, pension reform, program evaluation

Corresponding author:

John Piggott

Australian School of Business

University of New South Wales

Sydney 2052

Australia

E-mail: j.piggott@unsw.edu.au

\footnotetext{
* Data received from Statistics Norway and from the early retirement administration unit have been essential for the paper. We gratefully acknowledge support from the Research Council of Norway and the ARC Centre of Excellence in Population Ageing Research (CEPAR). We thank Fredrik Haugen, Steinar Holden, Ole Christian Lien, and participants at seminars at CEPAR and School of Economics at the University of New South Wales for valuable comments.
} 


\section{Introduction}

Demographic imperatives are triggering pension reforms, especially social security reform, in many countries. In general, the reforms address at least one of two broad objectives - to increase mature labor force participation, and to reduce the fiscal cost of pension outlays relative to tax revenues. Given these objectives, a natural policy change is to increase the pension access age, thus prescribing longer labor force attachment and reducing the life span of pension payouts. More than a dozen countries have either undertaken such a reform, or have announced plans to do so (OECD, 2012).While this almost certainly results in later retirement (Gruber and Wise, 1999 and 2004), it does so in a rather inflexible way as it imposes a uniform and often binding minimum retirement age on people who differ in terms of preferences, health, and job opportunities. It also typically generates a spill to disability insurance programs.

An alternative approach is to remove the disincentives to continue working beyond the pension access age by abolishing earnings tests and graduating payouts so that benefit deferral is appropriately rewarded. Such a policy allows individual workers the flexibility to decide independently both the retirement age and the age at which to claim benefit payments. This has been undertaken in far fewer countries: the US in 1983 and 2000, Canada and Sweden in the 1970s, the UK in 1989, Japan in 1985 and 2002, and Norway in 2011.

To choose the right policy mix of prescription and flexibility, policymakers need to have information on the expected labor supply responses to these different measures. In particular: How effective will the removal of taxes on labor implicit in the earnings test be as a tool to increasing mature labor supply?

In this paper we study the comprehensive 2011 Norwegian pension reform, using detailed longitudinal administrative data, to examine the labor supply responses to alternative reform paths. A key element of the Norwegian reform strategy was to avoid the presumed political controversies associated with higher access age, and instead focus on improving work incentives for workers above this age in combination with future automatic longevity adjustments of pension entitlements. However, as we explain in more detail below, the reform had widely different implications for different groups of workers, depending on pre-determined factors such as sector of employment and accumulated pension entitlements. Some workers were subject to changes in ac- 
cess age only (in both directions), some were subject to (large) changes in work incentives, and some were more or less unaffected. The reform therefore presents a surprisingly complete quasinatural experimental set-up for our investigations. No other country has simultaneously varied access age in both directions, introduced significant age-graduated benefits, and abolished earnings tests.

Our analysis is based on two complementary empirical strategies, both based on comprehensive administrative registers with panel data on employment and earnings for the first birth cohorts who were potentially affected by the reform and the last cohorts who were not affected. The first approach compares earnings and employment patterns before and after reform implementation for groups who were affected by it in different ways and directions. The second approach exploits the fact that individuals who primarily were subject to improvements in work incentives were affected to varying degrees depending on their (predetermined) earnings levels and past earnings histories. We compute the work incentives (actual and hypothetical) faced under the pre- and post- reform regimes, and examine the relationship between employment earnings and the two sets of work incentives, for both affected and unaffected cohorts. A causal relationship would predict that the partial positive correlation between labor supply and pre-reform and postreform calculated labor supply incentives, respectively, would shift toward post-reform calculated incentives after the reform, whereas a purely spurious relationship would leave the correlation patterns unchanged.

Our research builds on a substantial literature, particularly from the US, but also from Canada, the UK and Japan, examining labor supply responses to changes in social security rules. Much of this literature focuses on the bunching of labor supply decisions around particular earnings test thresholds. The earnings tests evaluated in these different countries have differed widely, however. While the earnings tests applied in the USA and the UK have been based on deferral of nonreceived benefits - largely at a rate believed to be actuarially fair - the earnings tests applied in Canada and Japan had no deferral, and could thus be considered a pure tax on labor earnings. From a theoretical point of view, we would thus expect the repeal or introduction of these different earnings tests to have very different labor supply implications. Several authors have argued, however, that even earnings tests with deferral may be perceived by the workers as a tax, possibly because the deferral schemes are complicated and poorly understood (e.g., Haider and 
Loughran, 2008), or because actuarial fairness does not apply for persons with high expected mortality (Engelhardt and Kumar, 2009).

It is not straightforward to compare results from evaluations of different reforms directly, since the characteristics and institutional setting of the reforms tend to vary a lot, e.g., in terms of the affected age group and the level of removed/installed earnings test thresholds. The typical finding, however, is that there are considerable labor supply responses to changes in earnings test thresholds, even when the earnings tests are designed to be actuarially fair; see Friedberg (2000), Song and Manchester (2007), Haider and Loughran (2008), and Engelhardt and Kumar (2009), for the US, Disney and Smith (2002) for the UK, Baker and Benjamin (1999) for Canada, and Shimizutani and Takeshi (2013) for Japan. Possible exceptions are the 1983 abolition of the earnings test in the US for persons aged 70-71 (Gruber and Orszag, 2003) and the 2002 reinstatement of the earnings test in Japan at a very high (around \$36,000) earnings threshold level (Shimizutani and Takeshi, 2013).

Our research also relates to existing Norwegian evidence. As a prelude to the major reform evaluated in the present paper, the earnings test in the Norwegian public pension system (without deferral) was lifted stepwise for ages 67-69 over the period 2008-2010. Empirical evaluations have found that this repeal, as well as an earlier increase in the threshold, caused substantial increases in labor supply at the intensive margin after the full retirement age (Hernaes and Jia, 2013; Brinch et al., 2013).

In the short run, it is likely that the labor supply responses to reforms changing the effective tax rate on labor earnings are modified by social norms and traditions. International comparisons clearly show that what pension systems define as the standard (full/normal) retirement age impacts the age of actual withdrawal from the labor market, even when economic incentives are not discontinuous at this particular age (Gruber and Wise, 1999; 2004). This is also confirmed by within-country studies. Mastrobuoni (2009), for example, found that increases in the standard retirement age in the US (the lowest access age for unreduced social security pension) on average increased the actual claiming age by roughly half the increase in the standard retirement age. Focusing on the retirement spike at the standard retirement age, Behaghel and Blau (2012) showed that the spike tended to increase in tandem with standard retirement age, despite the fact that nothing at all happened with the relative economic attractiveness of different claiming ages. 
These findings point toward behavioral economics explanations related to "reference dependence" (social norms) and/or loss aversion, and suggests that the "framing" of pension systems and pension reforms may be of considerable importance.

Reforms that effectively reduce access to - or the generosity of - early retirement programs may also embody the unintended side-effect of increasing the pressure on alternative subsidized escape routes from the labor market. A number of studies have found indications of "program substitution”, especially into disability insurance programs. Duggan et al. (2007) found that the reduced pension entitlements caused by increased standard retirement age from 65 to 67 in the US raised the percentage on disability programs between age 45 and 64 by 0.6 percentage points among men and 0.9 percentage points among women. Based on Austrian data, Staubli and Zweimuller (2011) found substantial increases in unemployment insurance claims following an increased early retirement access age. Previous Norwegian evidence also indicates that the phasing-in of a new and generous early retirement program in Norway during 1989-1994 reduced the numbers claiming disability pension significantly (Bratberg et al., 2004, Vestad, 2013), though its primary effect was to reduce employment (Røed and Haugen, 2002).

Viewed as a whole, the existing empirical evidence clearly shows that labor supply decisions among elderly persons do respond to economic incentives implicit in social insurance programs, but that the expected impacts of a given incentive-change are highly context-dependent. For pension systems with actuarially adjusted deferrals, transparency is likely to be a key factor; if individuals do not fully understand how curtailed benefits "today" are transformed to higher benefits "tomorrow", they may act as if a savings-scheme really is a pure tax. In addition, although deferrals are actuarially fair for the population as whole, individuals with short life-expectancy may correctly realize that there is a tax-element in the earnings test for them. A second factor of major importance is labor market flexibility; i.e., the extent to which elderly workers see realistic opportunities for continuing in employment, possibly with reduced hours. Rigidities may - at least for some time - conceal the true impact of new incentives on preferred employment and workhour patterns. Finally, the literature has demonstrated the importance of existing norms and established practices.

Our paper adds to the existing literature in several ways. First, we have access to data based upon an extraordinarily radical and swift reform process, in which incentives and access ages changed 
dramatically for some - but not all - workers virtually overnight and in a highly transparent fashion, with limited scope for pre-reform strategic behavior. One of the reform elements was to remove completely a confiscatory earnings test that, prior to the reform, applied to all labor earnings just slightly above zero. Second, as we explain in more detail below, we build our analysis on two different sources of identification which both arguably provide convincing evidence of causality. And third, by exploiting different aspects of the reform, we can directly compare the responses to two alternative reform strategies, based on raising the earliest access age (prescription) and on improving work incentives by eliminating earnings tests (flexibility), respectively.

Our findings show that the flexibility approach has the potential to raise labor supply considerably. We find that the repeal of the early retirement earnings test in the private sector (leaving the access age of 62 years unchanged) increased annual average earnings at age 63 (conditional on employment at age 60) in the first affected cohort by around \$14,700 (NOK 90,000 measured in 2013 value), corresponding to approximately $25 \%$ of average pre-reform earnings. ${ }^{1}$ Since the average net gain from continuing to work approximately doubled as a consequence of the reform, this also implies an uncompensated labor earnings elasticity - defined as the percentage change in average gross earnings divided by the percentage change in the average net returns to work - of around 0.25. Most of the labor supply response arose at the extensive margin, however, primarily by raising the probability of staying on in the labor market with roughly the same annual earnings level as before age 62 rather than pulling out of the labor market. It is notable that the labor supply responses we attribute to the pure flexibility reform (the removal of all earnings tests) were of similar magnitude as those we estimate for workers who were also subject to increased access age (prescription), while the latter also induced a spillover into increased disability. The effects of improved work incentives on the probability of continuing to work "as before” were almost the same for different types of workers distinguished by sex, education, previous earnings, work experience, and past sickness absence. Finally, we find that persons who as a result of the reform were subject to a lower access age to an actuarially fair early retirement pension (i.e., improved liquidity only) responded by reducing labor supply slightly at the intensive margin, while maintaining employment status unchanged.

\footnotetext{
${ }^{1}$ All the monetary amounts reported in this paper are inflated to 2013-value (using the Norwegian official pension benefit inflator, which in the period covered by this paper roughly corresponds to the wage growth), and then converted to USD (\$) with the exchange rate \$1=NOK 6.04.
} 


\section{Institutional setting}

Before the 2011 reform, the earliest access age for the public pension (social security; SSP) in Norway was 67 years, but around two thirds of workers had access to a supplementary early retirement system (hereafter referred to by its acronym AFP), in essence offering already from the age of 62 the full annual SSP workers would have received from age 67 had they continued in employment until this age (plus a fixed bonus equal to approximately $\$ 2000$ per year after tax). This early retirement pension was subjected to a full confiscatory earnings test, however, implying that continued labor earnings after retirement resulted in a proportional pension cut. With a full pension, the earnings test became effective from the first dollar earned. ${ }^{2}$ And with, for example, a $40 \%$ pension, the earnings test became effective once earnings exceeded $60 \%$ of preretirement normal earnings. There was no deferral option by delayed take-up, in effect implying very high implicit tax rates on continued work (we show below that these tax rates in some cases could exceed $100 \%$ ). Hence, the system represented a strong disincentive with respect to work after the age of 62, particularly for persons with relatively low wages.

The Norwegian 2011 pension reform implied large and immediate changes in the work incentives for many elderly workers. In this paper, we focus on two system parameters of paramount importance for labor supply: i) the earliest access age (EAA) and ii) the returns to continued work as determined by earnings tests and the degree of actuarial fairness in deferred pension entitlements. $^{3}$

The reform reduced the earliest access age to SSP from 67 to 62 years, but this early retirement option is based on an actuarially fair recalculation of annual benefits. ${ }^{4}$ Hence, it embodies no work disincentives at all. The new system is designed such that the decisions regarding the tim-

\footnotetext{
${ }^{2}$ To avoid adjustments in cases of "negligible” labor earnings, there was a so-called "tolerance amount" of approximately $\$ 2,000$ per year that could be earned without adjustment of benefits.

${ }^{3}$ The reform implied a number of fundamental changes in the Norwegian public pension system which are not part of the evaluation in this paper; the most important being i) a transition from a system where pension point accumulation was based on the 20 years with highest earnings to a system where all years count equally much, and ii) the introduction of automatic longevity-adjusted annuities, implying that future increases in longevity will result in lower annual pension entitlements. These reforms will be implemented gradually, however, such that those who were close to retirement age at the time of the reform were completely unaffected by them.

${ }^{4}$ Deferral calculations are based on average life-expectancy within birth-cohorts. This implies that individuals with shorter (longer) life-expectancy than the average may find the deferral scheme disadvantageous (advantageous) for them, and thus choose to draw on their pensions as early (late) as possible, regardless of labor supply behavior.
} 
ing of pension claims and the timing of employment have become decoupled; i.e., one is largely free to combine labor and pension income at will, as long as annual pension claims do not exceed the annuitized value of total pension wealth (lump sum withdrawal is thus not possible). ${ }^{5}$ Partial pension can be taken in steps of 20, 40, 50, 60, 80 and $100 \%$ of full annual pension. The percentage can be altered annually and a full pension can be taken out at any time. The actuarial adjustment implies that the annual pension becomes lower with early withdrawal. A precondition for early take-up is that the actuarially adjusted pension entitlement ensures a pension level at age 67 at least as high as the guaranteed pension, which is effective from that age. A number of individuals have so low entitlements that they are prevented from drawing a (full) pension at 62 and thus have to delay drawing, either until age 67 or until their adjusted entitlements provide a pension equal to the legislated minimum at age 67.

Concurrently with the social security reform, the AFP was also radically changed into an actuarially fair system for all private sector workers; i.e., the earnings test was completely removed, and the AFP-pension was redesigned to become a life-long top-up annuity that could be drawn only in combination with the SSP, with the annual amounts reduced in order to keep the total costs approximately unchanged. As a result, work incentives improved dramatically for the workers covered by this pension system. Based on the detailed data used in this paper, we have computed that the average net after-tax gain derived from continuing in employment one more year after age 62 (with the gross earnings level recorded at age 60 ) increased by as much as $\$ 28,260$. This corresponds to a reduction in the total tax rate (generated by both regular taxes and earnings tests) from around 75 to $45 \%$. Moreover, due to the imposition of a minimum pension entitlement as a precondition for early take-up, some workers previously covered by AFP actually lost or had to delay their early retirement option.

For public sector employees, the reform introduced the option of taking out SSP from age 62, subject to actuarial adjustment. However, in contrast to the actuarially adjusted private sector AFP, the public sector AFP has preserved the old confiscatory earnings-test and is still limited to the age range 62-67. Hence, workers in this sector of the economy still face strong labor supply disincentives, with average total tax rates close to $70 \%$. Moreover, the earnings-tested public

\footnotetext{
${ }^{5}$ Given the progressivity of the Norwegian tax system, it may still be economically advantageous for some workers to postpone pension take-out until they have reduced their annual labor earnings.
} 
sector AFP cannot be combined with early withdrawal of SSP. Still, for some of the workers who prior to the reform were at the margin between retiring with AFP and continue working as before while giving up their AFP entitlements, the latter alternative may have become more attractive as continued work can now be combined freely with early take-up of SSP benefits.

For those without AFP, the reform gave an opportunity to take out the public pension from age 62 instead of 67, but subject to actuarial adjustment and contingent on having a minimum level of entitlements. For those financially constrained, this opened up a previously non-existing early retirement option. The economic returns to work was not changed, however, as no earnings test was introduced.

Table 1. The Norwegian 2011 pension reform - overview of main consequences for six different worker groups. By predetermined AFP affiliation and SSP entitlements at age 62. (percent of workers in parentheses)

\begin{tabular}{|c|c|c|}
\hline & $\begin{array}{l}\text { Entitled to full early take-up of social security } \\
\text { pension (SSP) at age } 62 \text { after the reform }\end{array}$ & $\begin{array}{l}\text { Not entitled to full early take-up of social } \\
\text { security pension (SSP) at age } 62 \text { after the re- } \\
\text { form }\end{array}$ \\
\hline \multirow{2}{*}{$\begin{array}{l}\text { AFP public } \\
\text { sector }\end{array}$} & \multirow{2}{*}{$\begin{array}{l}\text { Group } 1(27 \%) \\
\text { No changes in either access age or work in- } \\
\text { centives. } \\
\text { New opportunity to start drawing on a full } \\
\text { SSP from age } 62 \text { (with actuarial recalculation } \\
\text { of benefits), conditional on giving up AFP } \\
\text { entitlements. }\end{array}$} & $\begin{array}{l}\text { Group } 4(13 \%) \\
\text { No changes in either access age or work in- } \\
\text { centives. }\end{array}$ \\
\hline & & $\begin{array}{l}\text { Depending on exact pension entitlements, a } \\
\text { new opportunity to start drawing on a reduced } \\
\text { (full) SSP at some time between age } 62 \text { and } 66 \\
\text { (with actuarial recalculation of benefits) condi- } \\
\text { tional on giving up AFP entitlements. }\end{array}$ \\
\hline \multirow[b]{2}{*}{$\begin{array}{l}\text { AFP private } \\
\text { sector }\end{array}$} & $\begin{array}{l}\text { Group } 2(23 \%) \\
\text { No change in the access age, but large im- } \\
\text { provements in work incentives. }\end{array}$ & $\begin{array}{l}\text { Group } 5 \text { ( } 4 \%) \\
\text { Increases in the access age (reduced liquidity) } \\
\text { and large improvements in work incentives. }\end{array}$ \\
\hline & $\begin{array}{l}\text { Flexibility: Continuation of the opportunity to } \\
\text { draw a full AFP/SSP from age } 62 \text {. Complete } \\
\text { removal of the old confiscatory earnings test } \\
\text { (actuarial recalculation of benefits). }\end{array}$ & $\begin{array}{l}\text { Prescription: No longer possible to claim a full } \\
\text { pension from age } 62 \text {. Depending on exact } \\
\text { pension entitlements, a new opportunity to } \\
\text { start drawing on a reduced (full) SSP and AFP } \\
\text { at some time between age } 62 \text { and } 66 \text { (with } \\
\text { actuarial recalculation of benefits). }\end{array}$ \\
\hline \multirow{2}{*}{$\begin{array}{l}\text { No AFP- } \\
\text { entitlement }\end{array}$} & $\begin{array}{l}\text { Group } 3(22 \%) \\
\text { Reductions in the access age (improved li- } \\
\text { quidity), but no changes in work incentives. }\end{array}$ & $\begin{array}{l}\text { Group } 6(12 \%) \\
\text { No changes in either access age or work in- } \\
\text { centives. }\end{array}$ \\
\hline & $\begin{array}{l}\text { Flexibility: New opportunity to draw a full } \\
\text { SSP from age } 62 \text {. No earnings test adjustment } \\
\text { (actuarial recalculation of benefits). }\end{array}$ & $\begin{array}{l}\text { Depending on exact pension entitlements, a } \\
\text { new opportunity to draw on a reduced (full) } \\
\text { SSP at some time between age } 62 \text { and } 66 \text { (with } \\
\text { actuarial recalculation of benefits). }\end{array}$ \\
\hline
\end{tabular}

Note: The percentage distribution is based on the analysis sample described in the next section. 
To sum up, Table 1 provides an overview of the main consequences of the reform for different worker groups, distinguished by i) their access to AFP and ii) their entitlements to (full) early take-out of SSP at the earliest access age (EAA). The six different groups identified in this table will play an important role in our empirical analysis.

Since the AFP system has been developed over several years through a tripartite agreement between the major associations of employers and employees and the state, the new reform package was also subject to negotiations between these parties. These negotiations took place in 2008 (the private sector) and 2009 (the public sector). From around May 2009, we can assume that all the main elements of the new early retirement system were known to the workers; i.e., around two years before the reform's implementation. This includes the "new" concept of actuarially fair deferral, which was forcefully communicated by policy makers and unions, as well as by the media. Note, however, that at this stage it was typically no longer possible for the workers to switch between the different AFP systems, as AFP entitlements in both the private and most of the public sector requires several years of sector-specific tenure.

Persons in the private sector who reached the age of 62 in 2010, the last year before the implementation of the reform in 2011, had the possibility of choosing between the "old” earnings tested AFP (which then had to be taken out before January 1, 2011) or waiting until January 2011 and then be eligible for the non-earnings-tested "new” AFP, life-long, but with a lower annual amount. A similar, but considerably less valuable, option was also offered to those in the four preceding cohorts who had not taken up the old AFP. ${ }^{6}$

\section{Data and empirical analysis}

The analyses in this paper are based on individual data from merged administrative registers. These files are linked by a unique encrypted personal identification numbers, and cover the entire population of Norway. The data provide detailed information on individual characteristics and labor market histories, and they are not plagued by the self-reporting and attrition problems common in survey-based records. Outcomes of interest include labor earnings (based on tax rec-

\footnotetext{
${ }^{6}$ These transitional rules applied for persons born from 1944 through 1947. The 1944 cohort (whose members were 66 at the time of the reform) were given $10 \%$ of the normal new AFP, the 1945 cohort $20 \%$, the 1946 cohort $40 \%$, and the 1947 cohort $60 \%$. The 1948-cohort, who reached the age of 62 in the last year prior to the reform, could obtain a full new AFP.
} 
ords), employment (defined on the basis of earnings), and social insurance claims (based on records from the social insurance administration), everything recorded in the calendar year persons reached age 63. The prevalence of social insurance claims may be of some importance, as it has been argued that early retirement options to some extent substitute for disability insurance benefits; see, e.g., Bratberg et al. (2004) and Vestad (2013).

Since earnings data are accurately recorded at the annual level only, all outcomes are measured in terms of whole calendar years. We avoid the year persons reached 62, since the reform effects in this year depend on the exact date of birth and since we only have access to annual earnings measures. We will be interested in both quantitative outcomes - such as the size of annual labor earnings - and in qualitative outcomes - such as employment versus non-employment and categories of employment derived from the earnings level at age 63 relative to the earnings level at age 60 .

Our empirical analysis will be based on workers who at age 60 were employed and not receiving any form of disability payment. The reason why we condition our analysis on employment at age 60 rather than 61 is that we wish to minimize possible endogeneity problems associated with early (ex ante) responses to changes in future work incentives. Since the new early retirement system was formed through the tariff agreements in 2008 and 2009 this does not necessarily eliminate the risk of endogeneity completely, as the members of the latest cohort used in our analysis (1949) reached the age of 60 in 2009 and, hence, could respond to the new incentive structures already in this year, e.g., by working more or less than they otherwise would have done. As part of a robustness analysis, we have therefore conditioned on employment at age 58 instead, but, as we show below, this did not change the results to any noticeable extent beyond introducing some extra measurement error in the mapping of persons into the six groups described in Table 1.

Our empirical strategy is based on two complementary approaches. The first exploits the fact that different groups of worker-types were affected in completely different ways by the reform some were subject to new work incentives, some were subject to changes in the earliest access age, some were subject to a combination of the two, and some were subject to almost no changes at all (Table 1). By comparing labor market outcomes for these worker groups just before and just after the reform potentially made its influence, we seek to identify the shifts that are directly 
attributable to the reform. The second approach takes advantage of the fact that within the worker-group exposed to new and improved work incentives (Group 2 in Table 1) the reform also generated some random-assignment-like incentives-differences between the last unaffected and the first affected cohorts. This makes it possible to examine the causal relationship between the sizes of the incentives changes and the sizes of the labor supply responses.

The main part of our analysis will be based on a comparison between the 1946-1947 birth cohorts - who reached 63 years in the two years prior to the reform (2009-2010) - and the 1949 cohort - who reached 63 in the year after the reform-year (2012). We drop the 1948 cohort from the statistical analysis, as its members were subject to a rather extraordinary set of work incentives in 2011. Those born the first 11 months of 1948 could choose between a (full) old AFP which then had to be taken out before the end of 2010 - or wait for the new AFP. Given that they did not choose the old AFP, work incentives improved sharply from 2011, just as for the subsequent cohorts. However, since 2010 was the very last chance to obtain the old AFP, persons who preferred this over the new one were constrained to take it out sooner rather than later, even if they ideally would have wished to wait another year or two. Hence, for this particular cohort, the reform had the paradoxical and unintended side effect of moving ahead some withdrawals from the labor market. ${ }^{7}$

From a macroeconomic viewpoint, the outcome period used in our statistical analysis (20092012) was relatively stable in Norway, with the aggregate (registered) rate of unemployment varying between 2.5 and $2.9 \%$ (2.7 \% of the labor force in 2009, $2.9 \%$ in 2010, back to $2.7 \%$ in 2011, and down to $2.5 \%$ in 2012); hence, we can more or less rule out that any significant changes in employment patterns were generated by cyclical fluctuations. As part of our descriptive overview, we also include two earlier birth cohorts (1944-1945) in order to assess the existence of pre-reform trends in the data.

${ }^{7}$ As described in the previous section, even workers belonging to the two pre-reform cohorts (1946-1947) were in principle affected by the reform from age 65 or 64, respectively, as they were then allowed to claim a strongly reduced new" AFP, provided that they had not already taken out the "old” AFP at that point. This could possibly have triggered higher labor supply already at age 63 and thus generated a corresponding reform effect even in our control group. While we will show here that there are no indications of such an effect in the data, it is worth noting that this would make us underestimate the true effects of the reform, and hence that the impact estimates reported for Group 2 in the present section are on the conservative side. 


\subsection{Comparing labor supply responses across groups}

We first compare labor market outcomes before and after the reform for persons belonging to the six different groups identified in Table 1. To assign persons to their correct group, we combine a number of data sources. First, to establish entitlement to AFP, we use the employer-employee register to identify workplace, and apply lists of affiliated firms obtained from the respective pension funds to establish annual firm membership. Also public-private sector classification of the work place was used and persons with ambiguous information were omitted. We then use individual records on tenure and overall work experience to establish whether individual eligibility criteria are satisfied, based on the assumption that they continue with their age 60 earnings levels and employment relationships until age $62 .{ }^{8}$ Second, to establish entitlement to early takeup of SSP, we use data on accumulated pension points obtained from the social security administration. The resulting "group assignment" is not perfect. For example, we see from the data that approximately $2 \%$ of individuals assumed to be ineligible for AFP actually turn out to claim AFP. A much larger fraction (around $8 \%$ ) of workers assumed to be ineligible for full early SSP actually claims early SSP. This does not necessarily represent a measurement error, however, as many of them are eligible for partial SSP.

${ }^{8}$ The individual eligibility criteria vary somewhat between sectors. In the private sector (which forms the basis for the main results of this paper), the most important criteria prior to the reform were: (i) current employment; (ii) at least 10 years of work experience since the age of 50; (iii) at least 3 years' tenure in the present firm or 5 years in firms operating the AFP; and (iv) an average of the 10 highest yearly incomes after 1966 exceeding an amount corresponding to at least one-third of an average full-time wage. After the reform, some of these requirements have become slightly less restrictive. In the definition of our groups, we nevertheless use the same requirements for all cohorts, to ensure full comparability. 
Table 2. Descriptive statistics. By group. Cohorts 1944 - 1947 and 1949. Conditional on employment at age 60.

\begin{tabular}{|c|c|c|c|c|c|c|c|c|c|c|c|c|}
\hline (3) & \multicolumn{2}{|c|}{$\begin{array}{c}\text { Group } 1 \\
\text { Public AFP } \\
\text { Access to early } \\
\text { SSP }\end{array}$} & \multicolumn{2}{|c|}{$\begin{array}{c}\text { Group } 2 \\
\text { Private AFP } \\
\text { Access to early } \\
\text { SSP } \\
\end{array}$} & \multicolumn{2}{|c|}{$\begin{array}{c}\text { Group } 3 \\
\text { No AFP } \\
\text { Access to early } \\
\text { SSP } \\
\end{array}$} & \multicolumn{2}{|c|}{$\begin{array}{l}\text { Group } 4 \\
\text { Public AFP } \\
\text { No access to } \\
\text { early SSP }\end{array}$} & \multicolumn{2}{|c|}{$\begin{array}{c}\text { Group } 5 \\
\text { Private AFP No } \\
\text { access to early } \\
\text { SSP } \\
\end{array}$} & \multicolumn{2}{|c|}{$\begin{array}{l}\text { Group } 6 \\
\text { No AFP } \\
\text { No access to } \\
\text { early SSP } \\
\end{array}$} \\
\hline Number of observations (N) & \multicolumn{2}{|c|}{43,339} & \multicolumn{2}{|c|}{36,628} & \multicolumn{2}{|c|}{35,762} & \multicolumn{2}{|c|}{20,710} & \multicolumn{2}{|c|}{6,318} & \multicolumn{2}{|c|}{19,387} \\
\hline Women & \multicolumn{2}{|c|}{0.47} & \multicolumn{2}{|c|}{0.17} & \multicolumn{2}{|c|}{0.12} & \multicolumn{2}{|c|}{0.97} & \multicolumn{2}{|c|}{0.91} & \multicolumn{2}{|c|}{0.71} \\
\hline Natives & \multicolumn{2}{|c|}{0.99} & \multicolumn{2}{|c|}{0.99} & \multicolumn{2}{|c|}{0.99} & \multicolumn{2}{|c|}{0.98} & \multicolumn{2}{|c|}{0.96} & \multicolumn{2}{|c|}{0.97} \\
\hline High school & \multicolumn{2}{|c|}{0.31} & \multicolumn{2}{|c|}{0.62} & \multicolumn{2}{|c|}{0.55} & \multicolumn{2}{|c|}{0.60} & \multicolumn{2}{|c|}{0.60} & \multicolumn{2}{|c|}{0.59} \\
\hline College & \multicolumn{2}{|c|}{0.64} & \multicolumn{2}{|c|}{0.19} & \multicolumn{2}{|c|}{0.28} & \multicolumn{2}{|c|}{0.18} & \multicolumn{2}{|c|}{0.04} & 0.1 & \\
\hline Earnings age 60 (1000 \$) & & & & & & & & & & & 54. & \\
\hline & Before & After & Before & After & Before & After & Before & After & Before & After & Before & After \\
\hline $\begin{array}{l}\text { Labor earnings (1000 \$) } \\
\text { Labor market state: } \\
\text { Employment }\end{array}$ & 68.5 & 72.9 & 59.0 & 71.5 & 84.1 & 82.8 & 40.1 & 42.7 & 31.4 & 41.5 & 43.0 & 44.2 \\
\hline $\begin{array}{l}\text {...with similar earnings as age } \\
60\end{array}$ & 0.51 & 0.56 & 0.34 & 0.45 & 0.54 & 0.49 & 0.51 & 0.53 & 0.33 & 0.49 & 0.51 & 0.51 \\
\hline $\begin{array}{l}\text {...with moderately reduced } \\
\text { earnings }\end{array}$ & 0.21 & 0.23 & 0.20 & 0.24 & 0.23 & 0.28 & 0.17 & 0.20 & 0.19 & 0.26 & 0.23 & 0.24 \\
\hline $\begin{array}{l}\text {...with strongly reduced earn- } \\
\text { ings }\end{array}$ & 0.14 & 0.11 & 0.23 & 0.17 & 0.12 & 0.13 & 0.14 & 0.13 & 0.20 & 0.13 & 0.12 & 0.12 \\
\hline $\begin{array}{l}\text { Non-employment } \\
\text {...with disability benefits }{ }^{\#}\end{array}$ & 0.02 & 0.02 & 0.03 & 0.03 & 0.04 & 0.03 & 0.04 & 0.04 & 0.06 & 0.08 & 0.07 & 0.06 \\
\hline ...without disability benefits & 0.11 & 0.08 & 0.20 & 0.10 & 0.06 & 0.07 & 0.13 & 0.11 & 0.21 & 0.04 & 0.07 & 0.07 \\
\hline AFP & 0.28 & 0.22 & 0.48 & 0.63 & 0.02 & 0.02 & 0.25 & 0.23 & 0.47 & 0.26 & 0.02 & 0.02 \\
\hline Social security pension (SSP) & - & 0.19 & - & 0.70 & - & 0.51 & - & 0.01 & - & 0.25 & - & 0.08 \\
\hline
\end{tabular}

Note: Groups are defined by AFP-affiliation and access to early SSP after the reform; see Table 1. "Similar earnings as age 60" is defined as having earnings at least as high as $90 \%$ of the age 60 level. "Moderately reduced earnings is defined as having earnings between 50 and $90 \%$ of the age 60 level, whereas "strongly reduced earnings" is defined as having earnings below $50 \%$ of the age 60 level, but still above $\$ 2000$.

\#Disability benefits include temporary as well as permanent disability insurance claims. 

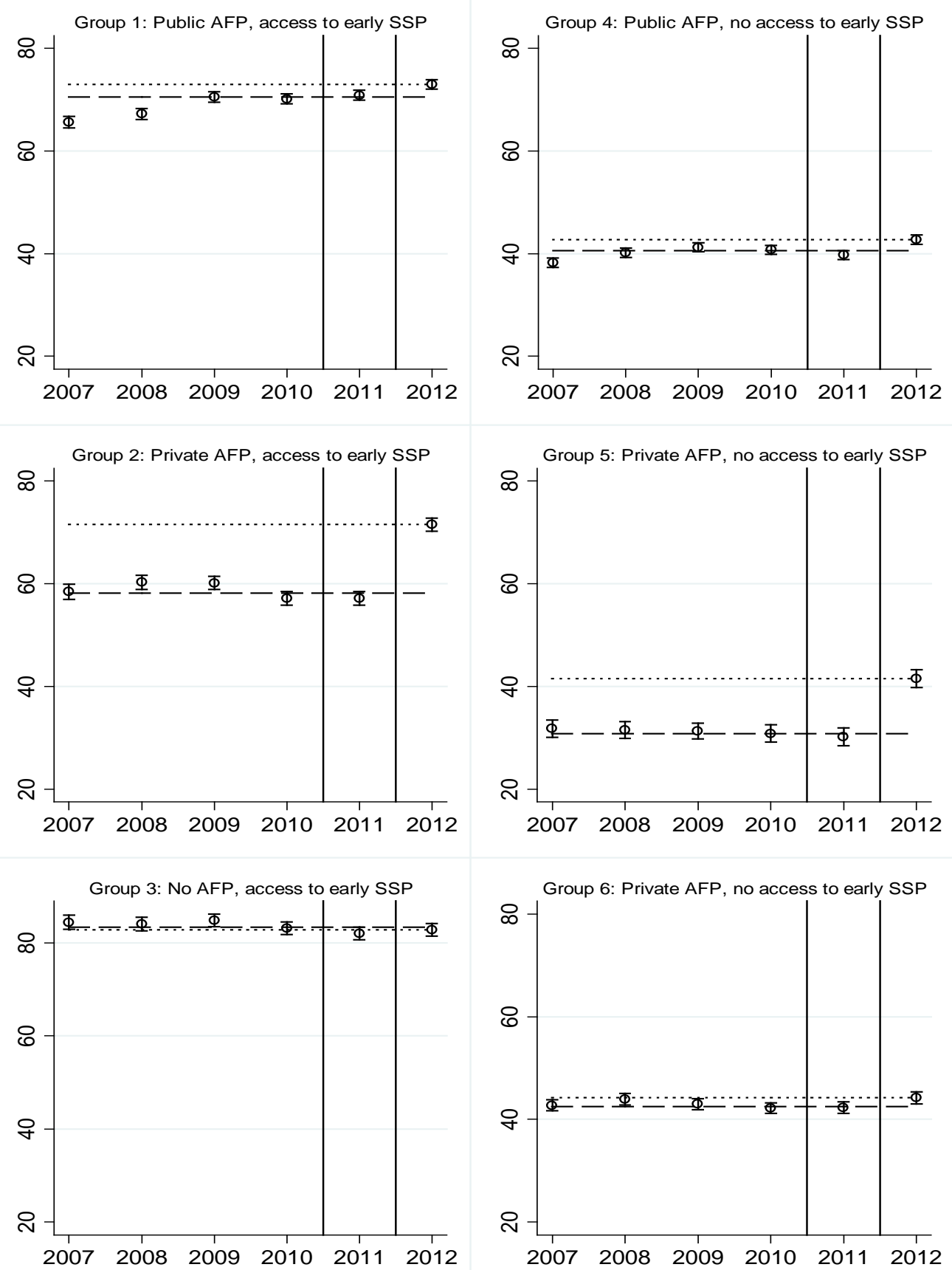

Figure 1. Annual earnings at age 63 (1000 \$) before and after the pension reform in 2011. By AFP and early SSP eligibility group.

Note: Groups are defined in Table 1. The graphs show annual earnings in the year of the sixty-third birthday. Each data point is marked with a 95\% confidence interval. The dashed horizontal line indicates the average age 63 earnings levels for the 1946 and 1947 birth cohorts (observed in 2009 and 2010) whereas the dotted horizontal line marks the corresponding average observed for the 1949-cohort (observed in 2012). The two vertical lines enclose the 1948-cohort (observed in 2011), which is dropped from all the statistical analyses reported in this paper due to some special circumstances applying for this cohort (explained in the text). 
Table 2 provides descriptive statistics for the six groups, including a number of pre-reform and post-reform labor market outcomes, whereas Figure 1 gives a graphical illustration of the development of the most important economic outcome (from which most of the others are derived): annual gross labor earnings at age 63. It is clear from these statistics that the six groups are very different in terms of composition, particularly with respect to gender, education, and initial earnings levels (at age 60), as well as outcomes (we use a common scale in the six panels of Figure 1 to illuminate the differences in earnings levels across the groups). It is also clear that the shifts in behavior from before to after the reform are largest in the two groups most strongly affected by the reform (Groups 2 and 5). However, we also see indications of positive labor supply shifts in some of the other groups, even though they were not - or only moderately - affected by the reform. Based on Figure 1, it is difficult to identify any clear pre-reform trend in labor supply. A possible exception is the public sector (Groups 1 and 4), where we see indications of rising annual earnings levels during the 2007-2009 period.

The two horizontal lines in each of the panels of Figure 1 mark the level of average earnings at age 63 for the last two unaffected cohorts (1946-1947) and for the first fully affected cohort (1949), respectively; hence the vertical distance between these two lines may be interpreted as a first indication of the sizes of possible reform effects. To come closer to an isolation of the true average effects of the reform for each of the six groups listed, we regress the individual outcome observations belonging to the 1946, 1947, and 1949 birth cohorts on a vector of individual covariates plus a dummy variable $R$ equal to one for the potentially reform-affected 1949-cohort (and zero for the other two cohorts). The regressions are made with ordinary least squares (OLS) separately for each group $g$, i.e.,

$$
y_{g i}=\mathbf{x}_{\mathbf{i}}{ }^{\prime} \beta_{g}+\alpha_{g} R+\varepsilon_{i}, \quad g=1, \ldots, 6 .
$$

The individual covariates $\mathbf{x}_{\mathbf{i}}$ include gender, education (nine fields of study and 8 levels defined by normal length of the education), country of origin (four groups: Western Europe including natives; Northern America and Oceania; Eastern Europe; Africa; and South America), and the level of labor earnings at age 58, 59 and 60.

The estimation results are presented in Table 3. We focus the discussion on the groups that were exposed to easily interpretable reforms of general interest. The members of Group 2 were subject 
to a pure improvement in work incentives; i.e., a flexibility reform. On average, the reform made it twice as economically profitable to continue working at the age-60-level as it had been prior to the reform (from $\$ 27,775$ to $\$ 56,033$ for the directly affected cohort). The regression result indicates that this caused annual gross labor earnings to increase by $\$ 14,713$, roughly $25 \%$ of the observed average pre-reform earnings level. Most of this effect came about by causing a larger fraction of the workers (13.0 percentage points) to continue working approximately as before; i.e., with similar earnings level as they had at age 60. But there was also an increase in the propensity to work a bit less than before (3.1 percentage points). The propensities to pull out of the work-force or to work only a little dropped sharply, apparently with no indirect effects on the level of disability insurance claims.

The members of Group 5 were - in addition to being subject to improved work incentives - also subject to an increase in the access age to a full pension. Hence, they no longer had the opportunity to claim a full pension already at age 63. According to our estimation results, they also responded by working a lot more, raising annual earnings by $\$ 10,744$. Given the low pre-reform earnings level in this group, the relative effect was as large as $34.2 \%$. Again, most of the effect came about by causing more workers (16.3 percentage points) to continue working as before. For this group, we also identify a considerable spillover effect to disability insurance programs, as the probability of claiming a temporary or permanent disability benefit at age 63 rose by 1.9 percentage points, $30 \%$ of the pre-reform level.

The members of Group 3 were subject to an improvement in liquidity only, as they gained access to an actuarially fair opportunity to start drawing on their pension wealth already from age 62 (instead of age 67). Our estimation results indicate that they responded to this new opportunity by working slightly less than they otherwise would have done $(-\$ 2,706)$. Employment did not decline significantly, however; instead the adjustment came about through a 4.0 percentage point reduction in the propensity to work "as before", matched by a 2.6 percentage point increase in the propensities to continue working with moderately reduced earnings and a 0.8 percentage point increase in the propensity to continue working with strongly reduced earnings. Hence, increased liquidity was primarily exploited to facilitate a slightly more gradual retirement path, not to exit the labor market at the first available opportunity. 
Table 3. Estimated reform effects on earnings and employment at age 63, conditional on employment at age 60 (standard errors in parentheses). Birth cohorts 1946, 1947, 1949 .

\begin{tabular}{|c|c|c|c|c|c|c|}
\hline & $\begin{array}{c}\text { Group } 1 \\
\text { Public AFP } \\
\text { Access to } \\
\text { early SSP }\end{array}$ & $\begin{array}{c}\text { Group } 2 \\
\text { Private AFP } \\
\text { Access to } \\
\text { early SSP }\end{array}$ & $\begin{array}{c}\text { Group } 3 \\
\text { No AFP } \\
\text { Access to } \\
\text { early SSP }\end{array}$ & $\begin{array}{c}\text { Group } 4 \\
\text { Public AFP } \\
\text { No access to } \\
\text { early SSP }\end{array}$ & $\begin{array}{c}\text { Group } 5 \\
\text { Private AFP } \\
\text { No access to } \\
\text { early SSP }\end{array}$ & $\begin{array}{c}\text { Group } 6 \\
\text { No AFP } \\
\text { No access to } \\
\text { early SSP }\end{array}$ \\
\hline Labor earnings (\$) & $\begin{array}{l}1,771^{* * *} \\
\quad(434)\end{array}$ & $\begin{array}{l}14,713^{* * *} \\
\quad(661)\end{array}$ & $\begin{array}{l}-2,706^{* * *} \\
(606)\end{array}$ & $\begin{array}{l}-123 \\
(456)\end{array}$ & $\begin{array}{c}10,744^{* * *} \\
(912)\end{array}$ & $\begin{array}{c}635 \\
(555)\end{array}$ \\
\hline \multicolumn{7}{|l|}{ Labor market state: } \\
\hline Employment & $\begin{array}{c}0.023^{* * *} \\
(0.004)\end{array}$ & $\begin{array}{l}0.111^{* * *} \\
(0.006)\end{array}$ & $\begin{array}{l}-0.005 \\
(0.004)\end{array}$ & $\begin{array}{l}0.019 * * \\
(0.007)\end{array}$ & $\begin{array}{c}0.154^{* * *} \\
(0.015)\end{array}$ & $\begin{array}{l}-0.001 \\
(0.007)\end{array}$ \\
\hline $\begin{array}{l}\text {...with similar earnings as age } \\
60\end{array}$ & $\begin{array}{c}0.023^{* * *} \\
(0.007)\end{array}$ & $\begin{array}{c}0.130 * * * \\
(0.007)\end{array}$ & $\begin{array}{c}-0.040^{* * *} \\
(0.007)\end{array}$ & $\begin{array}{c}0.000 \\
(0.010)\end{array}$ & $\begin{array}{c}0.163^{* * *} \\
(0.017)\end{array}$ & $\begin{array}{l}-0.003 \\
(0.010)\end{array}$ \\
\hline $\begin{array}{l}\text {...with moderately reduced } \\
\text { earnings }\end{array}$ & $\begin{array}{c}0.016^{* * *} \\
(0.005)\end{array}$ & $\begin{array}{c}0.031^{* * *} \\
(0.006)\end{array}$ & $\begin{array}{c}0.026 * * * \\
(0.006)\end{array}$ & $\begin{array}{l}0.017 * * \\
(0.007)\end{array}$ & $\begin{array}{c}0.050 * * * \\
(0.015)\end{array}$ & $\begin{array}{c}0.000 \\
(0.009)\end{array}$ \\
\hline $\begin{array}{l}\text {...with strongly reduced earn- } \\
\text { ings }\end{array}$ & $\begin{array}{c}-0.016^{* * *} \\
(0.004)\end{array}$ & $\begin{array}{c}-0.049 * * * \\
(0.006)\end{array}$ & $\begin{array}{l}0.008 * \\
(0.005)\end{array}$ & $\begin{array}{c}0.001 \\
(0.006)\end{array}$ & $\begin{array}{c}-0.058^{* * *} \\
(0.014)\end{array}$ & $\begin{array}{c}-0.004 \\
(0.007)\end{array}$ \\
\hline \multicolumn{7}{|l|}{ Non-employment } \\
\hline ...with disability benefits ${ }^{\#}$ & $\begin{array}{c}-0.004^{* *} \\
(0.002)\end{array}$ & $\begin{array}{c}0.002 \\
(0.002)\end{array}$ & $\begin{array}{c}-0.004 \\
(0.003)\end{array}$ & $\begin{array}{c}0.002 \\
(0.004)\end{array}$ & $\begin{array}{c}0.019 * * \\
(0.009)\end{array}$ & $\begin{array}{c}-0.001 \\
(0.005)\end{array}$ \\
\hline ...without disability benefits ${ }^{\#}$ & $\begin{array}{c}-0.019 * * * \\
(0.004)\end{array}$ & $\begin{array}{c}-0.113^{* * *} \\
(0.005)\end{array}$ & $\begin{array}{c}0.008 * * \\
(0.003)\end{array}$ & $\begin{array}{c}-0.021^{* * *} \\
(0.006)\end{array}$ & $\begin{array}{c}-0.173^{* * *} \\
(0.013)\end{array}$ & $\begin{array}{c}0.002 \\
(0.005)\end{array}$ \\
\hline Number of observations (N) & 27,566 & 23,393 & 23,039 & 12,565 & 3,741 & 11,548 \\
\hline
\end{tabular}

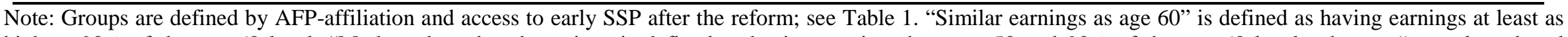

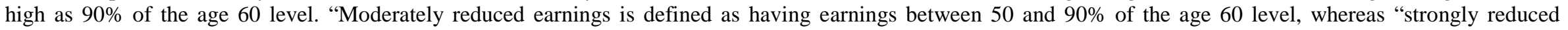

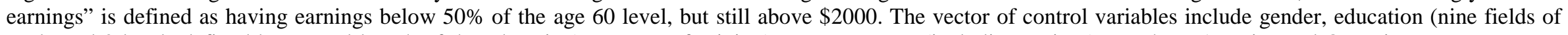

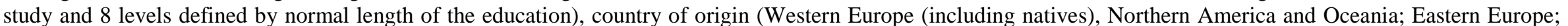
Africa; and South America), and the level of earnings at age 58, 59 and 60. $\left.{ }^{* * *}\right)\left({ }^{* * *}\right)$ indicates statistical significant at the 10(5)(1) percent level.

\#Disability benefits include temporary as well as permanent disability insurance claims. 
We also estimate positive labor supply effects of the reform in Group 1, whose members did not experience any changes in either the returns to work or in access age, but who gained the opportunity to start drawing on the SSP entitlements (provided that they disavowed their AFP entitlements) in combination with continued work. This effect is to some extent observed even in group 4, whose members did not qualify for a full SSP pension at age 63, but who nevertheless may have found it attractive to combine continued work with access to a partial SSP. Our interpretation of this finding is that some employees found it more attractive to continue in employment after it became possible to combine this with early pay-out of the social security pension. For group 6, whose members had no access to either AFP or a full SSP pension from age 62, we estimate no reform effects at all.

In the policy debate leading up to the Norwegian pension reform it was argued, particularly by some labor unions, that the new flexibility primarily would be exploited by well-off workers in good and comfortable jobs that could easily be extended beyond the age of 62. More generally, it was pointed out that employment opportunities at this high age are unequally distributed, and hence that an actuarially fair early retirement system could become a new important source of economic inequality. In the political economy of pension reform, distributional concerns clearly play an important - sometimes decisive - role. And if groups of worn-out workers are unable (or unwilling) to supply more labor after the age of 62 regardless of the work incentives they face, these workers will tend to become the losers in a reform that substitutes an actuarially fair pension subsidy to everyone for an earnings-tested subsidy targeted at those who leave the labor market early. It is therefore of some interest to examine the extent to which the behavioral responses to the new pension system did differ across different types of workers. To shed light on this, we estimate some of the reform effects separately for a number of subgroups, distinguished by sex, education, previous earnings, labor market experience, and health (the latter proxied by past sickness absence). This analysis is limited to Group 2 (improved work incentives) and Group 3 (improved liquidity), as the other groups are either of limited interest due to the absence of a significant reform (Groups 1, 4, and 6) or too small to be split up in several subgroups (Group 5). 
Table 4. Estimated reform effects of improved work incentives on earnings and employment at age 63, conditional on employment at age 60 (standard errors in parentheses). Group 2 (Private AFP. Access to early SSP). Birth cohorts 1946, 1947, 1949.

\begin{tabular}{|c|c|c|c|c|c|c|c|c|}
\hline & $\mathrm{I}$ & II & III & IV & $\mathrm{V}$ & VI & VII & VIII \\
\hline & Men & Women & $\begin{array}{l}\text { Max } 12 \text { years } \\
\text { education and } \\
\text { Min } 40 \text { years } \\
\text { work experi- } \\
\text { ence at age } 62\end{array}$ & $\begin{array}{l}\text { College or } \\
\text { University } \\
\text { degree }\end{array}$ & $\begin{array}{c}\text { Earnings at } \\
\text { age 58-60 } \\
\text { below medi- } \\
\text { an in whole } \\
\text { analysis pop. }\end{array}$ & $\begin{array}{l}\text { Earnings at } \\
\text { age 58-60 } \\
\text { above medi- } \\
\text { an in whole } \\
\text { analysis pop. }\end{array}$ & $\begin{array}{l}\text { No long-term } \\
\text { sick-leave at } \\
\text { age 53-60 }\end{array}$ & $\begin{array}{c}\text { Some long- } \\
\text { term sick- } \\
\text { leave at age } \\
53-60\end{array}$ \\
\hline Labor earnings (\$) & $\begin{array}{l}14,806 * * * \\
(764)\end{array}$ & $\begin{array}{c}14,045 * * * \\
(1,217)\end{array}$ & $\begin{array}{l}13,994 * * * \\
\quad(715)\end{array}$ & $\begin{array}{c}19,231 * * * \\
(2,061)\end{array}$ & $\begin{array}{l}10,474^{* * *} \\
\quad(727)\end{array}$ & $\begin{array}{l}16,553^{* * *} \\
\quad(917)\end{array}$ & $\begin{array}{c}14,079 * * * \\
(1,021)\end{array}$ & $\begin{array}{c}15,020^{* * *} \\
(845)\end{array}$ \\
\hline [Pre-reform level] & {$[108,685]$} & {$[87,063]$} & {$[94,664]$} & {$[148,984]$} & {$[68,431]$} & {$[122,746]$} & {$[114,401]$} & {$[96,575]$} \\
\hline \multicolumn{9}{|l|}{ Labor market state: } \\
\hline \multicolumn{9}{|l|}{ Employment } \\
\hline $\begin{array}{l}\ldots \text { with similar earnings as } \\
\text { age } 60\end{array}$ & $\begin{array}{c}0.121 * * * \\
(0.007)\end{array}$ & $\begin{array}{l}0.162 * * * \\
(0.016)\end{array}$ & $\begin{array}{l}0.126 * * * \\
(0.008)\end{array}$ & $\begin{array}{c}0.137 * * * \\
(0.016)\end{array}$ & $\begin{array}{c}0.120^{* * *} \\
(0.011)\end{array}$ & $\begin{array}{c}0.133^{* * *} \\
(0.008)\end{array}$ & $\begin{array}{c}0.124^{* * *} \\
(0.010)\end{array}$ & $\begin{array}{c}0.133^{* * *} \\
(0.009)\end{array}$ \\
\hline $\begin{array}{l}\text {...with moderately reduced } \\
\text { earnings }\end{array}$ & $\begin{array}{c}0.037 * * * \\
(0.007)\end{array}$ & $\begin{array}{c}0.009 \\
(0.139)\end{array}$ & $\begin{array}{c}0.041^{* * *} \\
(0.007)\end{array}$ & $\begin{array}{c}0.009 \\
(0.014)\end{array}$ & $\begin{array}{c}0.052 * * * \\
(0.010)\end{array}$ & $\begin{array}{c}0.021^{* * *} \\
(0.007)\end{array}$ & $\begin{array}{l}0.019 * * \\
(0.009)\end{array}$ & $\begin{array}{c}0.042 * * * \\
(0.008)\end{array}$ \\
\hline $\begin{array}{l}\text {...with strongly reduced } \\
\text { earnings }\end{array}$ & $\begin{array}{c}-0.053^{* * *} \\
(0.006)\end{array}$ & $\begin{array}{c}-0.031^{* *} \\
(0.013)\end{array}$ & $\begin{array}{c}-0.056^{* * *} \\
(0.007)\end{array}$ & $\begin{array}{c}-0.039 * * * \\
(0.012)\end{array}$ & $\begin{array}{c}-0.040^{* * *} \\
(0.010)\end{array}$ & $\begin{array}{c}-0.053^{* * *} \\
(0.007)\end{array}$ & $\begin{array}{c}-0.051^{* * *} \\
(0.008)\end{array}$ & $\begin{array}{c}-0.047 * * * \\
(0.008)\end{array}$ \\
\hline \multicolumn{9}{|l|}{ Non-employment } \\
\hline ...with disability benefits ${ }^{\#}$ & $\begin{array}{c}0.003 \\
(0.003)\end{array}$ & $\begin{array}{l}-0.003 \\
(0.005)\end{array}$ & $\begin{array}{c}0.004 \\
(0.003)\end{array}$ & $\begin{array}{l}-0.003 \\
(0.003)\end{array}$ & $\begin{array}{c}0.006 \\
(0.006)\end{array}$ & $\begin{array}{c}0.000 \\
(0.002)\end{array}$ & $\begin{array}{c}0.002 \\
(0.002)\end{array}$ & $\begin{array}{c}0.003 \\
(0.004)\end{array}$ \\
\hline $\begin{array}{l}\text {... without disability bene- } \\
\text { fits }^{\#}\end{array}$ & $\begin{array}{c}-0.108^{* * *} \\
(0.006)\end{array}$ & $\begin{array}{c}-0.137 * * * \\
(0.012)\end{array}$ & $\begin{array}{c}-0.115^{* * *} \\
(0.007)\end{array}$ & $\begin{array}{c}-0.104 * * * \\
(0.011)\end{array}$ & $\begin{array}{c}-0.137 * * * \\
(0.010)\end{array}$ & $\begin{array}{c}-0.102^{* * *} \\
(0.006)\end{array}$ & $\begin{array}{c}-0.094 * * * \\
(0.007)\end{array}$ & $\begin{array}{c}-0.130 * * * \\
(0.008)\end{array}$ \\
\hline Number of observations (N) & 19,128 & 4,265 & 16,002 & 4,427 & 7,645 & 15,748 & 10,965 & 12,428 \\
\hline
\end{tabular}

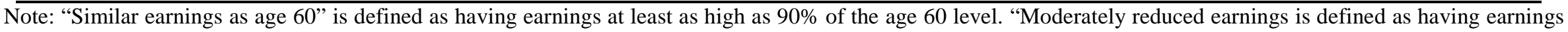

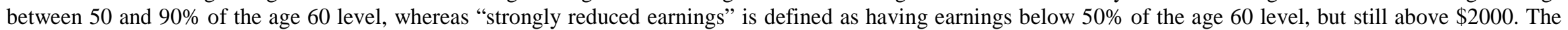

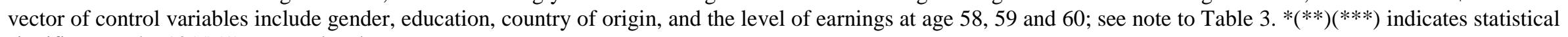
significant at the 10(5)(1) percent level.

"Disability benefits include temporary as well as permanent disability insurance claims. 
Table 5. Estimated reform effects of lower access age to an actuarially fair early retirement pension (improved liquidity), conditional on employment at age 60 (standard errors in parentheses). Group 3 (No AFP. Access to early SSP). Birth cohorts 1946, 1947, 1949.

\begin{tabular}{|c|c|c|c|c|c|c|c|c|}
\hline & Men & Women & $\begin{array}{l}\text { III } \\
\text { Max } 12 \text { years } \\
\text { education and } \\
\text { Min } 40 \text { years } \\
\text { work experi- } \\
\text { ence at age } 62\end{array}$ & $\begin{array}{l}\text { College or } \\
\text { University } \\
\text { degree }\end{array}$ & $\begin{array}{c}\mathrm{V} \\
\text { Earnings at } \\
\text { age 58-60 } \\
\text { below medi- } \\
\text { an in whole } \\
\text { analysis pop. }\end{array}$ & $\begin{array}{c}\text { VI } \\
\text { Earnings at } \\
\text { age 58-60 } \\
\text { above medi- } \\
\text { an in whole } \\
\text { analysis pop. }\end{array}$ & $\begin{array}{l}\text { No long-term } \\
\text { sick-leave at } \\
\text { age 53-60 }\end{array}$ & $\begin{array}{c}\text { VIII } \\
\text { Some long- } \\
\text { term sick- } \\
\text { leave at age } \\
53-60\end{array}$ \\
\hline Labor earnings (\$) & $\begin{array}{c}-3,187 * * * \\
(663)\end{array}$ & $\begin{array}{c}303 \\
(1,417)\end{array}$ & $\begin{array}{l}-2,529 * * * \\
(716)\end{array}$ & $\begin{array}{c}-3,259 * * \\
(1,288)\end{array}$ & $\begin{array}{l}-3,460 * * * \\
(735)\end{array}$ & $\begin{array}{l}-2,275^{* * *} \\
(842)\end{array}$ & $\begin{array}{l}-2,760 * * * \\
(844)\end{array}$ & $\begin{array}{l}-2,252^{* * *} \\
(859)\end{array}$ \\
\hline [Pre-reform level] & {$[104,690]$} & {$[96,364]$} & {$[92,659]$} & {$[131,067]$} & {$[60,613]$} & {$[128,141]$} & {$[110,783]$} & {$[95,859]$} \\
\hline \multicolumn{9}{|l|}{ Labor market state: } \\
\hline \multicolumn{9}{|l|}{ Employment } \\
\hline $\begin{array}{l}\ldots \text { with similar earnings as } \\
\text { age } 60\end{array}$ & $\begin{array}{c}-0.043^{* * *} \\
(0.007)\end{array}$ & $\begin{array}{l}-0.020 \\
(0.019)\end{array}$ & $\begin{array}{c}-0.044^{* * *} \\
(0.009)\end{array}$ & $\begin{array}{c}-0.032 * * \\
(0.013)\end{array}$ & $\begin{array}{c}-0.066^{* * *} \\
(0.012)\end{array}$ & $\begin{array}{c}-0.027^{* * *} \\
(0.009)\end{array}$ & $\begin{array}{c}-0.035^{* * *} \\
(0.010)\end{array}$ & $\begin{array}{c}-0.043^{* * *} \\
(0.010)\end{array}$ \\
\hline $\begin{array}{l}\text {...with moderately reduced } \\
\text { earnings }\end{array}$ & $\begin{array}{c}0.025^{* * *} \\
(0.007)\end{array}$ & $\begin{array}{l}0.037 * * \\
(0.017)\end{array}$ & $\begin{array}{c}0.028 * * * \\
(0.008)\end{array}$ & $\begin{array}{c}0.022 * * \\
(0.011)\end{array}$ & $\begin{array}{l}0.032 * * * \\
(0.010)\end{array}$ & $\begin{array}{c}0.023 * * * \\
(0.008)\end{array}$ & $\begin{array}{c}0.023 * * * \\
(0.009)\end{array}$ & $\begin{array}{c}0.030 * * * \\
(0.009)\end{array}$ \\
\hline $\begin{array}{l}\text {...with strongly reduced } \\
\text { earnings }\end{array}$ & $\begin{array}{l}0.011 * * \\
(0.005)\end{array}$ & $\begin{array}{l}-0.007 \\
(0.011)\end{array}$ & $\begin{array}{c}0.009 \\
(0.006)\end{array}$ & $\begin{array}{c}0.010 \\
(0.008)\end{array}$ & $\begin{array}{l}0.017 * * \\
(0.008)\end{array}$ & $\begin{array}{c}0.005 \\
(0.006)\end{array}$ & $\begin{array}{l}0.012 * * \\
(0.006)\end{array}$ & $\begin{array}{c}0.004 \\
(0.007)\end{array}$ \\
\hline \multicolumn{9}{|l|}{ Non-employment } \\
\hline ...with disability benefits ${ }^{\#}$ & $\begin{array}{l}-0.002 \\
(0.003)\end{array}$ & $\begin{array}{c}-0.015^{* *} \\
(0.007)\end{array}$ & $\begin{array}{l}-0.007^{*} \\
(0.004)\end{array}$ & $\begin{array}{c}0.003 \\
(0.003)\end{array}$ & $\begin{array}{l}-0.008 \\
(0.006)\end{array}$ & $\begin{array}{l}-0.001 \\
(0.003)\end{array}$ & $\begin{array}{c}-0.006 * * * \\
(0.002)\end{array}$ & $\begin{array}{l}-0.003 \\
(0.005)\end{array}$ \\
\hline $\begin{array}{l}\text {...without disability bene- } \\
\text { fits }^{\#}\end{array}$ & $\begin{array}{c}0.009 * * \\
(0.004)\end{array}$ & $\begin{array}{c}0.005 \\
(0.009)\end{array}$ & $\begin{array}{c}0.014 * * * \\
(0.004)\end{array}$ & $\begin{array}{l}-0.004 \\
(0.006)\end{array}$ & $\begin{array}{c}0.026 * * * \\
(0.007)\end{array}$ & $\begin{array}{l}-0.000 \\
(0.004)\end{array}$ & $\begin{array}{c}0.006 \\
(0.004)\end{array}$ & $\begin{array}{c}0.012 * * \\
0.005)\end{array}$ \\
\hline Number of observations (N) & 20,103 & 2,936 & 13,574 & 6,543 & 8,128 & 14,911 & 12,039 & 11,000 \\
\hline
\end{tabular}

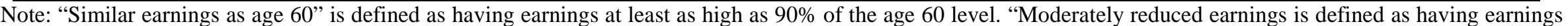

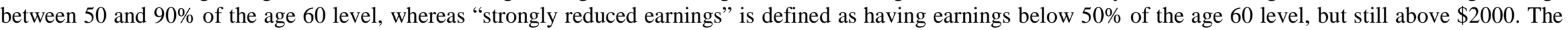

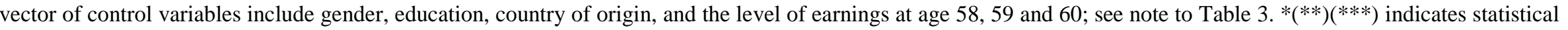
significant at the 10(5)(1) percent level.

${ }^{\#}$ Disability benefits include temporary as well as permanent disability insurance claims. 
Looking first at the impacts of improved work incentives (Table 4), there is a remarkable similarity in the labor supply responses across the different subgroups. The probability of continuing with approximately the same earnings as at age 60 increased by 12-13 percentage points in all the male-dominated subgroups (recall that men constitute $83 \%$ of the workers in Group 2) regardless of education, earnings levels, work experience, and past sickness absence. Notably, low-skilled workers with at least 40 years of work experience did not respond differently than other (male) workers. For women, the probability of continuing as before increased by as much as 16 percentage points. Focusing on the level of labor earnings instead, we find (unsurprisingly) a larger impact on the typical high earnings groups (columns IV and VI). Relative to the prereform earnings level at age 63 (reported in brackets), the responses were similar across all groups. It is also notable that we find no evidence whatsoever of a spillover effect to disability insurance in any of the subgroups.

Moving on to the impacts of improved liquidity arising from lower access age to own pension wealth (Table 5), we again find very similar responses across all the male-dominated subgroups (in Group 3, men constitute $88 \%$ of the workers). There was a small negative earnings effect in all these groups, caused by a shift toward moderately reduced hours. Hence, all types of male workers apparently took advantage of the new flexibility to choose a more gradual exit path from the labor market. For women, however, we see no such effect. There was an increase in the propensity to continue with reduced hours even for women, but to a large extent this substituted for disability insurance rather than for a continuation of the age-60 employment level. Also for some of the other subgroups, we see indications of spillover to disability insurance. Taken together with the evidence reported above (based on Group 5) we can conclude that modifications of the access age have some consequences for the frequency of disability insurance claims, regardless of whether the pension system is actuarially fair or not. Earlier access to own pension wealth reduces disability pension claims.

As discussed in the introduction to this section, there is a theoretical possibility that some persons in the 1949-cohort adjusted their labor supply behavior in response to the forthcoming pension reform already at age 60 , in which case it would be a questionable strategy to treat earnings and employment at age 60 as completely exogenous. To address this concern, we have performed a robustness analysis on our main results (Table 3), conditioning on employment and 
earnings at age 58 instead (with outcomes also defined relative to age 58 earnings and the past earnings explanatory variables covering age 56-58 instead of age 58-60). The price we pay for this modification is that the group assignment (into the six effect groups distinguished in Table 1) is subject to more measurement error, since we have to extrapolate base-year earnings up to age 62 to compute entitlements. The results from this exercise are presented in the Appendix. Consistent with a measurement error (contamination) interpretation they indicate somewhat weaker effects in the groups with the largest estimated effects and somewhat stronger effects in the groups with no or very small reform effects. But the main pattern is very similar.

\subsection{Comparing labor supply responses for workers with different incentives changes}

Given that the labor supply responses to improved work incentives were similar across the different worker groups as defined by e.g., gender, education, and past earnings, it is tempting to investigate whether we can establish a causal relationship between the sizes of the incentives change and the sizes of the responses conditional on these factors. To do this, we compute the hypothetical pre-reform and post-reform work incentives for everyone in Group 2 (workers with private sector AFP and access to early SSP in the new system) - both for cohorts who were actually subject to the new incentives and for those who were not. To illustrate the within-group differences in "treatment-dosage", Figure 2, panel (a), shows the density of the distribution of the net take-home pay associated with working one more year for 63 year-olds in Group 2 (based on a continuation of the gross income level that applied at age 60 and after earnings tests and relevant tax rules have been taken into account) before and after the reform. It is clearly seen that the returns-to-work distribution shifted to the right as a consequence of the reform. Panels (c) and (d) show the distribution of individual differences between new and old incentives, in absolute terms (1000\$) and relative to previous gross earnings (at age 60), respectively. While the average net economic returns to working one more year increased by $\$ 28,260$, the variation across workers was considerable, and the individual gains ranged from around $\$ 22,000$ to $\$ 35,000$, or from around 20 to 80 percent of previous gross earnings. The variation was driven by a combination of nonlinearities in the AFP system (with a relatively high floor and a low ceiling), differences in earnings and pension point accumulation, and by the progressive nature of the tax system. However, as illustrated by the cross-plot in panel (b) of Figure 2, it is a very strong correlation between pre-reform and post-reform returns to work. This represents a challenge when we seek to 
identify the causal impacts of work incentives based on the reform-generated within-group variation only. We therefore do not perform a subgroup analysis based on this method, but limit our attention to the incentives and response variations within Group 2 as a whole.
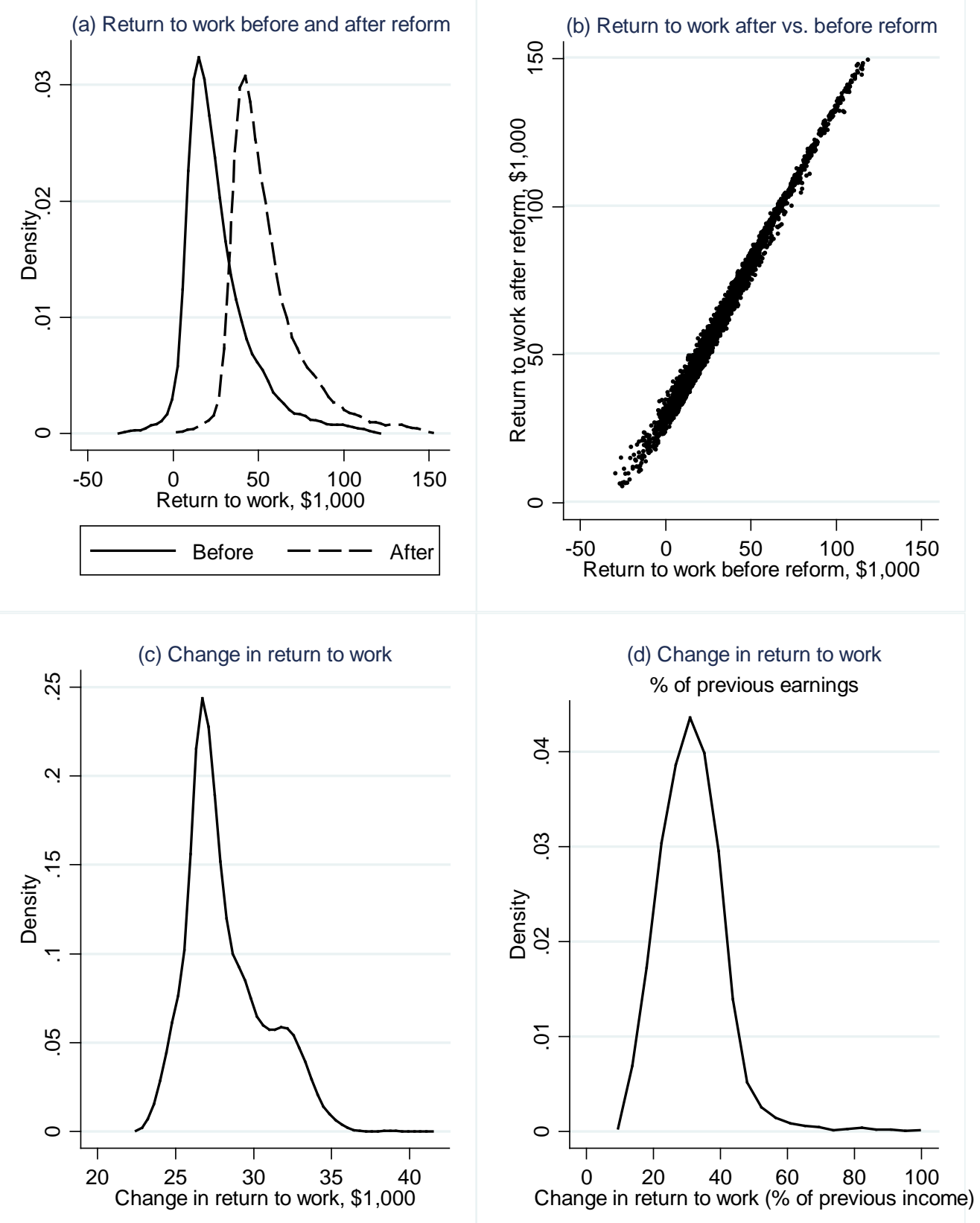

Figure 2. The distribution of net (after tax) economic returns to working one more year at age 63 before and after the reform with the gross earnings level recorded at age 60 Note: Data based on the actually affected birth cohort in Group 2 only (7,605 observations). 
To the extent that the observed increases in employment and earnings after the reform can really be attributed to the reform, we would expect to see larger responses the larger were the improvement in work incentives. Unfortunately, it is not possible to observe the same individuals' age-63-behavior both before and after the reform; hence we cannot examine the relationship between individual changes in labor supply and individual changes in incentives. What we can do, however, is to examine labor supply outcome for the pre- and post-reform birth cohorts at different fixed positions in the hypothetical incentives-change-distribution. Figure 3 illustrates: Here, we have divided each birth-cohort into deciles, based on individual positions in the distribution of hypothetical incentives changes relative to age-60-earnings. For each of these deciles, we then report in Figure 3 the difference between average labor market outcomes at age 63 for the affected 1949-cohort (with outcomes measured in 2012) and for the two unaffected 1946/1947-cohorts (with outcomes measured in 2009/2010): see panels (a) and (c). These graphs indicate a strong upwards sloping relationship between the sizes of the incentives changes and the sizes of the earnings changes. For example, whereas the members of the decile subject to an improvement in work incentives corresponding to around $40 \%$ of previous earnings increased labor earnings at age 63 by around $30 \%$, the decile subject to an improvement of "only” around $20 \%$ of previous earnings increased labor earnings by around $20 \%$. As a sort of “placebo” analysis, panels (b) and (d) show exactly the same picture for the changes observed between the two pre-reform years. As expected, no systematic relationship can be identified between hypothetical reform-initiated incentives changes and changes in labor supply. 


\section{Labor earnings age 63}
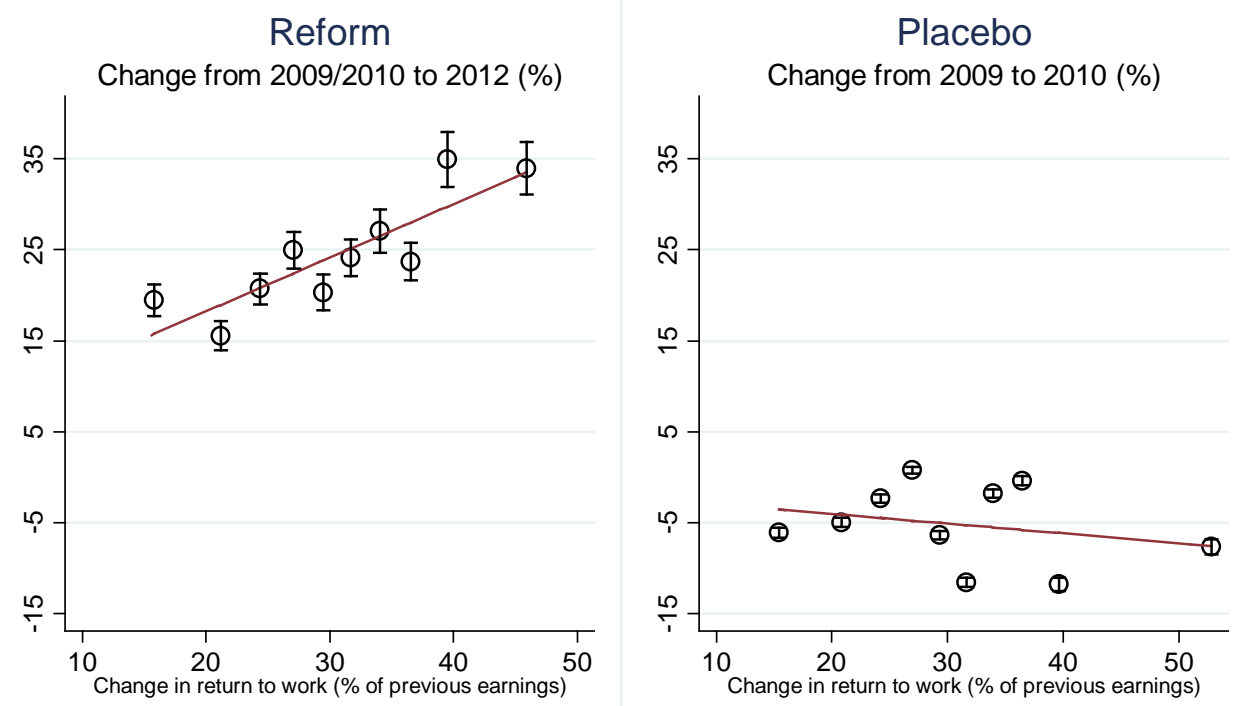

\section{Employment age 63}
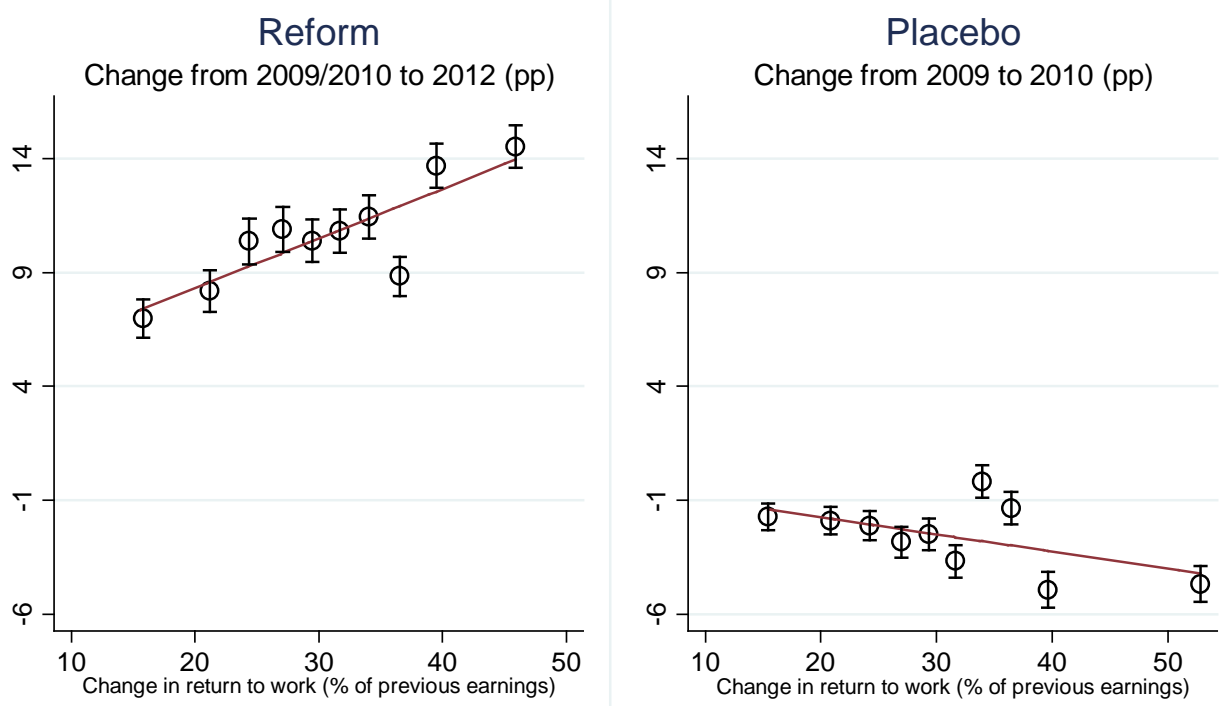

Figure 3. Labor earnings and employment earnings at age 63 for each decile in the distribution of hypothetical changes in the returns to work generated by the pension reform. Change from 2009/2010 to 2012 and from 2009 to 2010. Vertical bars indicate 95 \% point-wise confidence intervals. 
We now turn to a more formal statistical analysis intended to exploit the reform-initiated variation in incentives across cohorts (within Group 2) to quantify the causal relationship between labor supply and work incentives. In general, we expect labor supply incentives to be anything but randomly assigned, as persons with different wage levels are likely to differ systematically along other dimensions as well, such as health status, motivation, job characteristics, and valuation of leisure. Hence, in order to facilitate estimation of the causal relationship between work incentives and labor supply, we need to isolate the random-assignment-like variation generated by the reform. We do this by estimating regressions where we not only include the actual work incentive as the central explanatory variable, but also add in the corresponding hypothetical prereform and post-reform work incentives. The basic idea is that while the spurious correlations between labor supply and pre and post-reform work incentives should be the same before and after the reform, the causal effect should shift toward the incentives actually applying. Hence, by studying changes in the correlation patterns from before to after the reform, we can trace out the causal effects. More specifically, we set up regression models that link labor market outcomes directly to the economic returns to work for the members of Group 2:

$$
y_{i}=\mathbf{x}_{\mathbf{i}}{ }^{\prime} \lambda+\varphi \Delta_{i}^{A}+\delta \Delta_{i}^{O}+\gamma \Delta_{i}^{N}+\varepsilon_{i},
$$

where $\left(\Delta_{i}^{A}, \Delta_{i}^{O}, \Delta_{i}^{N}\right)$ are individual i's net economic returns to work (to be specified more precisely below) as they actually apply $\left(\Delta_{i}^{A}\right)$ and as they would have applied under the old $\left(\Delta_{i}^{O}\right)$ and new $\left(\Delta_{i}^{N}\right)$ pension systems, respectively. The vector of control variables $\mathbf{x}_{\mathbf{i}}$ again includes gender, education (nine fields and eight levels), country of origin for immigrants (five regions), labor earnings at age 58, 59 and 60, and - in some specifications - cohort dummy variables.

The coefficient of interest is $\varphi$, which represents the causal effect of the work incentive on the outcome variable $y_{i}$. Now, if we let $R_{i}$ be a reform dummy (a variable equal to one for the cohort affected by the reform and zero otherwise) we clearly have that $\Delta_{i}^{A}=R_{i} \Delta_{i}^{N}+\left(1-R_{i}\right) \Delta_{i}^{O}$; hence Equation (1) can also be written $y_{i}=\mathbf{x}_{\mathbf{i}}{ }^{\prime} \lambda+\left(\delta+\varphi\left(1-R_{i}\right)\right) \Delta_{i}^{O}+\left(\gamma+\varphi R_{i}\right) \Delta_{i}^{N}+\varepsilon_{i}$, which highlights that the causal effect $\varphi$ is identified by the "extra” correlations that arise in the periods in which the two respective incentive variables actually apply. If the vector of individual covariates $\mathbf{x}_{\mathbf{i}}$ includes cohort/time dummy variables (obviously also incorporating the reform-dummy $R_{i}$ ), it 
is only the idiosyncratic changes in work incentives that identify the effects of interest; hence the source of identification become orthogonal to the one used to identify the group-specific shifts in the previous subsection. However, since the reform involved a considerable improvement in work incentives for all the members of Group 2, it is clear that we then also "throw away" much of the information content in the data. If the vector of covariates does not include cohort/time dummy variables, on the other hand, we obtain valid estimates of $\varphi$ only under the assumption that no other unaccounted for factors shifted labor supply at age 63 from the 1946-1947 to the 1949 cohort (conditional on all the covariates included in $\mathbf{x}_{\mathbf{i}}$ ).

We focus on two outcomes in this analysis; i.e., the level of annual labor earnings and employment. We also restrict attention to those who worked close to full time at age 60 (dropping 398 observations with earnings below $\$ 50,000$ at age 60). For annual earnings at age 63, we assume a linear relationship between the gross earnings level and the size of the net economic gain associated with continue working at the level recorded at age $60 .{ }^{9}$ This relationship captures a combination of differences in labor supply responses (employment and/or hours) and differences in the earnings-consequences of given labor supply changes. For the employment outcome, we assume a linear relationship between the dichotomous employment indicator and the gain associated with continue working relative to the earnings level recorded at age $60 .^{10}$

The estimation results are presented in Table 6. Whereas Column I report results for the models where we impose the restriction of a stable economic environment apart from the reform (no cohort dummy variables), Column II reports results for the models where we include cohort/time dummy variables, essentially isolating the "idiosyncratic" part of the reform-generated incentives differences; i.e., the part that is orthogonal to both the hypothetical levels of pre- and post-reform incentives and to the cohort dummy variables. The standard errors increase a lot from the first to the second of these identification strategies, reflecting the modest degree of idiosyncratic variation. The explanation for this can be seen in Figure 2, panel (b), which illustrates the high corre-

\footnotetext{
${ }^{9}$ Note that it is difficult to estimate this equation in a log-linear form, since the net gain from working under the old pension system sometimes was negative $\left(\Delta_{i}^{o}<0\right)$, and also since the outcome in many cases takes the value of zero.

${ }^{10} \mathrm{~A}$ logit specification yields similar results as those presented below.
} 
lation between new and old work incentives and thus the little variation that can be expected to remain when the average levels differences are controlled for through cohort dummy variables.

Our point estimates for the gross earnings effect indicate that if the net annual returns to continued employment (with labor supply as at age 60) increases by, say, \$1000, actual gross earnings increases by around $\$ 500-650$, ceteris paribus. For the employment outcome, we find that if the gain increases by, say, 10 \% of initial (age 60) earnings, the employment probability increases by around 2.4-3.5 percentage points. As shown by the implied reform effects reported in brackets, the estimates are consistent with the findings reported in the previous subsection.

Table 6. Estimated impact on annual earnings and employment at age 63 of the economic returns to work. Standard errors in parentheses. Implied average reform effects in brackets, measured in US\$ or probabilities. $95 \%$ confidence intervals for implied overall reform effects in brackets.

\begin{tabular}{|c|c|c|}
\hline & $\begin{array}{c}\text { I } \\
\text { Without cohort } \\
\text { dummy variables }\end{array}$ & $\begin{array}{c}\text { II } \\
\text { With cohort dummy } \\
\text { variables }\end{array}$ \\
\hline $\begin{array}{l}\text { Impact on annual gross labor earnings of a marginal } \\
\text { increase in the annual net returns to work }\end{array}$ & $\begin{array}{c}0.531^{* * *} \\
(0.023) \\
{[\$ 13,732, \$ 16,289]}\end{array}$ & $\begin{array}{c}0.665^{* *} \\
(0.257) \\
{[\$ 4,558, \$ 33,028]}\end{array}$ \\
\hline $\begin{array}{l}\text { Impact on employment probability of a marginal in- } \\
\text { crease in the annual net returns to work relative to the } \\
\text { age } 60 \text { earnings level }\end{array}$ & $\begin{array}{c}0.347 * * * \\
(0.018) \\
{[0.10,0.12]}\end{array}$ & $\begin{array}{c}0.242 * * * \\
(0.064) \\
{[0.04,0.12]}\end{array}$ \\
\hline Cohort/time dummies included & No & Yes \\
\hline Number of observations (N) & 22,995 & 22,995 \\
\hline
\end{tabular}

Note: The sample includes individuals working in the year they are 60 in the birth cohorts 1946-1947 and 1949, with age-60 earnings above $\$ 50,000$. Implied reform effects are computed by multiplying the estimated effect with the average difference in the relevant incentive variable for the affected cohort (between the pre and post reform systems). The vector of control variables include gender, education (nine fields of study and 8 levels defined by normal length of the education), country of origin (Western Europe, Northern America and Oceania; Eastern Europe; Africa; and South America), and the level of earnings at age 58, 59 and $60 . *(* *)(* * *)$ indicates significance at the 10(5)(1) percent level.

\section{Discussion and concluding remarks}

Like many other countries, Norway entered this century with a pension system considered to be fiscally unsustainable in an ageing society. For the majority of workers, the pension system implied a strong incentive to retire fully already at age 62. A consensus had emerged among policy makers and stakeholders that mature labor supply needed to be encouraged. Two possible reform 
avenues were discussed: To increase the earliest access age (leaving annual pension benefits untouched) or to remove all disincentives to work while claiming pension benefits (leaving the access age untouched). The latter "flexibility approach" implied the removal of earnings tests and the introduction of actuarially fair deferral of unclaimed benefit entitlements. It involved no immediate fiscal savings. To the contrary, in the short run it actually entailed extra pension outlays, as the direct savings from the earnings test disappeared.

Norwegian policy makers opted for flexibility as the main early retirement reform strategy. But a small minority of workers was also subjected to higher access age, as a new threshold was set on the level of pension point accumulation required for early take-up. Furthermore, the parliament legislated that in the future, all pension annuities will automatically be adjusted to changes in each cohort's expected longevity. From a political perspective, this pension reform package may have appeared more "marketable" than a general rise in the access age, as very few workers actually lost anything in the short run, whereas most of the expected fiscal savings materialize gradually and without the need for new political decisions. And when the pension cuts due to longevity adjustments start to bite after some time, workers can decide for themselves whether to adapt by accepting lower annual pension or by working more intensively or for longer in order to maintain the current benefit level. For the first generation of retirees, the reform actually represented a significant improvement, as they could take advantage of the new-won possibility of working and claiming pension benefits at the same time - at their own choosing.

The merits of this reform strategy clearly hinges on the magnitudes of the labor supply responses it triggers. In this paper, we have examined the immediate labor supply responses for the first (fully) affected cohort. Our main finding is that the responses were large. For example, the immediate effect of the removal of the earnings test was to increase annual labor earnings at age 63 by around $\$ 14,700$ (25 \%). This suggests that the “flexibility approach" is a viable alternative to a more strict prescription policy of higher access age. Our results actually indicate that the added labor supply effect obtained by also raising the access age is small. Moreover, whereas higher access age entails a significant spillover to disability pension programs, no such fiscally adverse side-effects are identified for those who were exposed to improved work incentives only. In addition to help solving fiscal challenges, the flexibility approach has the obvious advantage that it fosters social welfare by letting each person decide his/her individual retirement profile in ac- 
cordance with preferences and circumstances. The heterogeneity within retiring cohorts is thus recognized.

Prior to the reform's implementation, there was a widespread concern that the new flexibility primarily would be exploited by well-off workers with comfortable jobs, and that worn-out workers with low education, low earnings, and long employment careers would not see continued work as a realistic (or desirable) alternative. Our analysis concludes that workers with low education, long work careers (more than 40 years), and low previous earnings exploited the new flexibility option as much as other workers. Flexibility appears to have been a valued systemattribute in all worker groups. At the same time, poverty among the retirees has effectively been prevented by the take-up requirements.

The results presented in this paper, as well as other recent studies on preceding pension rules adjustments in Norway (Hernæs and Jia, 2013; Brinch et al., 2013) point to a more elastic labor supply behavior among elderly workers than most of the existing literature indicates. Like all country specific studies, these findings probably partly reflect contextual features of the reform process, as well as the design of the reform itself. First, the new and improved work incentives were forcefully communicated and subject to a lot of media attention. In contrast to what has been claimed regarding the deferral scheme in the US, it is highly unlikely that many of the affected workers in Norway misinterpreted the pension deferral scheme as being a pure tax. Our results then fit well with the finding of Chan and Stevens (2008) that "... well-informed people respond much more than previously thought". Second, but somewhat related, the feature of the new early retirement system that allowed the deferral of pension benefits to be decided individually - independently of the labor supply decision - has probably contributed to prevent such misunderstandings. Moreover, the opportunity to combine labor earnings and pension benefits at will appears to have been highly valued, as a majority of those who decided to continue working as before nevertheless chose to start drawing on the pension benefits immediately. And third, the Norwegian pension reform was implemented at a time of macroeconomic stability and relatively low unemployment. There was a demand for the mature workers, and probably also to some extent a willingness among employers to allow "attractive” elderly workers to continue with reduced hours. 
Previous empirical evidence indicates that changing established employment patterns among elderly persons is at best a slow-moving process, and that stagnant social norms and traditions probably play a significant role in offsetting the labor supply effects of incentives-focused pension reforms. Nevertheless, based on more recent data, we have shown in this paper that transparent, substantial, and successfully communicated improvements in work incentives may constitute a highly effective strategy for increasing mature labor supply. If these results are supported by studies elsewhere, they will have major implications for pension reform designed to increase mature labor force participation. In a rapidly ageing society, it is likely that age-specific work-norms are in motion, and, hence are more malleable than ever before. Current population dynamics may thus enhance the impact of pension reforms designed to reduce work disincentives for elderly workers.

\section{References}

Baker, M. and Benjamin, D. (1999). 'How do retirement tests affect the labor supply of older men?, The Journal of Public Economics, Vol. 71, pp. 27-51.

Behaghel, L. And Blau, D. M. (2012) 'Framing Social Security Reform: Behavioral Responses to Changes in the Full Retirement Age'. American Economic Journal: Economic Policy, 4(4): 41-67.

Bratberg, E., Holmås, T. H. and Thøgersen, Ø. (2004) Assessing the effects of an early retirement program. Journal of Population Economics, 17: 387-408

Brinch, C., Hernaes, E. and Jia, Z (2013) 'Earnings Distribution and Labour Supply after a Retirement Earnings Test Reform', Oxford Bulletin of Economics and Statistics, Volume 75, June 2013, No 13.

Chan, S. and Stevens, A. H. (2008) What You Don’t Know Can’t Help You: Pension Knowledge and Retirement Decision-Making. The Review of Economics and Statistics, Vol. 90(2), pp. 253 - 266.

Dahl, S. Nilsen, O and Vaage, K. (2003).'Gender differences in early retirement behavior', European Sociological Review, Vol. 19, pp. 179-98.

Disney, R. and Smith, S. (2002). 'The labor supply effect of the abolition of the earnings rule for older workers in the United Kingdom’ The Economic Journal, Vol. 112, pp. C136-52. 
Duggan, M, Singleton, P and Song, J. (2007). 'Aching to retire? The rise in the full retirement ag and its impact on the social security disability rolls'. Journal of Public Economics 91, pp 1327-1350

Engelhardt, G. V and Kumar, A. (2009). 'The repeal of the retirement earnings test and the labor supply of older men’. Journal of Pension Economics and Finance, Cambridge University Press doi:10.1017/S1474747208003892

French, E. (2005). 'The Effects of Health, Wealth, and Wages on Labor Supply and Retirement Behavior', Review of Economic Studies, Vol. 72, pp. 395-427.

Friedberg, L. (2000). 'The Labor Supply Effects of the Social Security Earnings Test', The Review of Economics and Statistics, Vol. 82, pp. 48-63.

Friedberg, L. and Webb, A (2006). 'Persistence in Labor Supply Effect and the response to the Social Security Earnings Test’, Center for Retirement Research, Boston College. http://escholarship.bc.edu/retirement_papers/138

Gruber, J. and Orszag, P. (2003). 'Does the Social Security Earnings Test Affect Labor Supply and Benefits Receipt?’ National Tax Journal, Vol. LVI, pp. 755-73.

Gruber, J. and Wise, D. A. (1999) Social Security and Retirement around the World NBER The University of Chicago Press.

Gruber, J. and Wise, D. A. (2004) Social Security Programs and Retirement around the World. Micro-Estimation NBER The University of Chicago Press.

Haider, S. J. and Loughran, D. S. (2008). 'The effect of the Social Security Earnings Test on Male Labor Supply’, The Journal of Human Resources, Vol. XLIII, pp.57-87.

Hernaes, E. and Jia, Z. (2013). 'Earnings Distributions and Labor Supply after a Retirement Earnings Test Reform', Oxford Bulletin of Economics and Statistics, Vol. 75, Issue 3, pp. 410-434.

Mastrobuoni, G. (2009). 'Labor supply effects of the recent social security benefit cuts: Empirical estimates using cohort discontinuities’. Journal of Public Economics, 93, 1224 $-1233$.

OECD (2012). ‘Pensions Outlook 2012’. OECD Publishing. http://dx.doi.org/10.1787/9789264169401-en

Røed, K. and Haugen (2003) Retirement and Economics Incentives: Evidence from a Quasinatural Experiment. Labour 17(2) 203-228 
Shimizutani, S. and Oshio, T. (2013). 'Revisiting the labor supply effect of social security earnings test: New evidence from its elimination and reinstatement in Japan’ Japan and the World Economy, 28(2013) 99 - 111.

Song, J. G. and Manchester, J. (2007). 'New evidence on earnings and benefits claims following changes in the retirement earnings test in 2000'. Journal of Public Economics, Vol. 91, pp. 669-700.

Staubli, S. and Zweimuller, J. (2011) Does Raising the Retirement Age Increase Employment of Older Workers? Working Paper No 20, University of Zurich

Vestad, O. (2013) Labour supply effects of early retirement provision Labour Economics, Volume 25, pp 98-109

The Ministry of Labour and Social Inclusion. (2006). 'Chapter 1: Governmental White Paper No. 5 (2006-2007)'.

http://www.regjeringen.no/en/dep/aid/Topics/pensions.html?id=939 


\section{Appendix}

Table A1 presents the main results from Section 3.1 (Table 3) conditioned on employment at age 58 instead of at age 60 (see the note to the table for details).

\section{Table A1. Estimated reform effects, conditional on employment at age 58 (standard errors in parentheses). Birth cohorts 1946, $1947,1949$.}

\begin{tabular}{|c|c|c|c|c|c|c|}
\hline & $\begin{array}{c}\text { Group } 1 \\
\text { Public AFP } \\
\text { Access to } \\
\text { early SSP }\end{array}$ & $\begin{array}{c}\text { Group } 2 \\
\text { Private AFP } \\
\text { Access to } \\
\text { early SSP }\end{array}$ & $\begin{array}{c}\text { Group } 3 \\
\text { No AFP } \\
\text { Access to } \\
\text { early SSP } \\
\end{array}$ & $\begin{array}{c}\text { Group } 4 \\
\text { Public AFP } \\
\text { No access to } \\
\text { early SSP }\end{array}$ & $\begin{array}{c}\text { Group } 5 \\
\text { Private AFP } \\
\text { No access to } \\
\text { early SSP }\end{array}$ & $\begin{array}{c}\text { Group } 6 \\
\text { No AFP } \\
\text { No access to } \\
\text { early SSP }\end{array}$ \\
\hline Labor earnings (\$) & $\begin{array}{l}3,648 * * * \\
\quad(460)\end{array}$ & $\begin{array}{l}11,876^{* * * *} \\
\quad(690)\end{array}$ & $\begin{array}{l}-3,515^{* * *} \\
(646)\end{array}$ & $\begin{array}{l}1,468 \\
(470)\end{array}$ & $\begin{array}{l}8,573 * * * \\
\quad(936)\end{array}$ & $\begin{array}{c}4 \\
(571)\end{array}$ \\
\hline \multicolumn{7}{|l|}{ Labor market state: } \\
\hline \multicolumn{7}{|l|}{ Employment } \\
\hline $\begin{array}{l}\text {...with similar earnings as age } \\
58\end{array}$ & $\begin{array}{l}0.042^{* * *} \\
(0.006)\end{array}$ & $\begin{array}{l}0.081^{* * *} \\
(0.007)\end{array}$ & $\begin{array}{c}-0.059 * * * \\
(0.006)\end{array}$ & $\begin{array}{l}0.022 * * \\
(0.009)\end{array}$ & $\begin{array}{l}0.113^{* * * *} \\
(0.017)\end{array}$ & $\begin{array}{l}-0.010 \\
(0.009)\end{array}$ \\
\hline $\begin{array}{l}\text {...with moderately reduced } \\
\text { earnings }\end{array}$ & $\begin{array}{c}0.007 \\
(0.005)\end{array}$ & $\begin{array}{l}0.060 * * * \\
(0.006)\end{array}$ & $\begin{array}{c}0.040^{* * *} \\
(0.006)\end{array}$ & $\begin{array}{l}0.013^{*} \\
(0.007)\end{array}$ & $\begin{array}{c}0.057 * * * \\
(0.015)\end{array}$ & $\begin{array}{c}0.005 \\
(0.008)\end{array}$ \\
\hline $\begin{array}{l}\text {...with strongly reduced earn- } \\
\text { ings }\end{array}$ & $\begin{array}{c}-0.023^{* * *} \\
(0.004)\end{array}$ & $\begin{array}{l}-0.044^{* * *} \\
(0.006)\end{array}$ & $\begin{array}{l}0.008 * \\
(0.005)\end{array}$ & $\begin{array}{l}-0.010 \\
(0.006)\end{array}$ & $\begin{array}{c}-0.037^{* * * *} \\
(0.014)\end{array}$ & $\begin{array}{c}0.000 \\
(0.007)\end{array}$ \\
\hline \multicolumn{7}{|l|}{ Non-employment } \\
\hline ...with disability benefits ${ }^{\#}$ & $\begin{array}{c}-0.008^{* * *} \\
(0.002)\end{array}$ & $\begin{array}{c}0.007 \\
(0.003)\end{array}$ & $\begin{array}{c}-0.006 * * \\
(0.003)\end{array}$ & $\begin{array}{c}-0.004 \\
(0.006)\end{array}$ & $\begin{array}{l}0.023^{*} \\
(0.012)\end{array}$ & $\begin{array}{c}-0.004 \\
(0.006)\end{array}$ \\
\hline ...without disability benefits ${ }^{\#}$ & $\begin{array}{c}-0.018^{* * *} \\
(0.004)\end{array}$ & $\begin{array}{c}-0.098^{* * *} \\
(0.005)\end{array}$ & $\begin{array}{c}0.017 * * \\
(0.003)\end{array}$ & $\begin{array}{c}-0.022^{* * *} \\
(0.006)\end{array}$ & $\begin{array}{c}-0.156^{* * *} \\
(0.013)\end{array}$ & $\begin{array}{l}0.010 * \\
(0.006)\end{array}$ \\
\hline Number of observations (N) & 28,409 & 22,658 & 25,212 & 13,309 & 3,712 & 13,132 \\
\hline
\end{tabular}

Note: Groups are defined by AFP-affiliation and access to early SSP after the reform; see Table 1. "Similar earnings as age 58” is defined as having earnings at least as high as $90 \%$ of the age 58 level. "Moderately reduced earnings is defined as having earnings between 50 and $90 \%$ of the age 58 level, whereas "strongly reduced earnings" is defined as having earnings below 50\% of the age 58 level, but still above \$2000. The vector of control variables include gender, education (nine fields of study and 8 levels defined by normal length of the education), country of origin (Western Europe, Northern America and Oceania; Eastern Europe; Africa; and South America), and the level of earnings at age 56, 57 and 58. $\left.*^{* *}\right)(* * *)$ indicate statistical significant at the 10(5)(1) percent level.

\#Disability benefits include temporary as well as permanent disability insurance claims. 